\title{
Belgeo
}

Revue belge de géographie

\section{The prospects of Chinese firms in an opening economy: Breaking away from the "flying geese" patternor turning into another case of East Asian ersatz capitalism?}

Les perspectives des firmes chinoises dans une économie qui s'ouvre: rupture avec le modèle en "vol d'oies sauvages" ou nouveau cas d'ersatz de capitalisme est-asiatique?

Jean-Christophe Defraigne

\section{(2) OpenEdition}

Journals

Electronic version

URL: http://journals.openedition.org/belgeo/12276

DOI: $10.4000 /$ belgeo.12276

ISSN: 2294-9135

Publisher:

National Committee of Geography of Belgium, Société Royale Belge de Géographie

\section{Printed version}

Date of publication: 30 September 2005

Number of pages: $275-306$

ISSN: 1377-2368

Electronic reference

Jean-Christophe Defraigne, "The prospects of Chinese firms in an opening economy: Breaking away from the "flying geese" patternor turning into another case of East Asian ersatz capitalism?", Belgeo [Online], 3 | 2005, Online since 28 October 2013, connection on 05 February 2021. URL: http:// journals.openedition.org/belgeo/12276 ; DOl: https://doi.org/10.4000/belgeo.12276

This text was automatically generated on 5 February 2021.

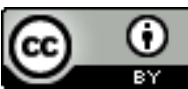

Belgeo est mis à disposition selon les termes de la licence Creative Commons Attribution 4.0 International. 


\section{The prospects of Chinese firms in an opening economy: Breaking away from the "flying geese" patternor turning into another case of East Asian ersatz capitalism?}

Les perspectives des firmes chinoises dans une économie qui s'ouvre: rupture avec le modèle en "vol d'oies sauvages" ou nouveau cas d'ersatz de capitalisme est-asiatique?

Jean-Christophe Defraigne

\section{Introduction}

1 It has become quite common to read economic forecasts predicting that China's GDP will catch up with Japan's GDP in 2010 and with US' GDP in 2020. Outlining the successes of firms like Haier, Kelon or Lenovo (formerly Legend), some analysts perceive the emergence of world class Chinese multinational enterprises that would eventually catch up with their Asian and Western counterparts (FT, 2003, 21/12). Chinese firms would be a similar situation today than the Japanese keiretsu or the Korean chaebol at the beginning of their international expansion. Some even claim that China could "leapfrog" technologically the newly industrialised countries of East Asia like South Korea. 


\section{The flying geese pattern}

\section{The successive waves of Japanese FDI and the industrialisation of East Asia}

2 According to this view, China would break the so-called "flying geese" pattern that has been characterizing the East Asian economies for the last decades. The "flying geese" theory was first conceived by Akamatsu Kaname, a Japanese scholar in the 1930s. It emphasized the role that the Japanese economy could play in the development of the emerging East Asian economies (Yamamura, 1997, p. 27). Massive flows of Japanese FDI across the region would create an industrial base and technological spin-offs that would induce successive take-offs of Japan's neighbours as Japanese multinational enterprises (MNEs) would accelerate their geographic expansion in Asia. The development of the East Asian economies would resemble the characteristic "Vshaped" flight of geese with the Japanese economy playing the role of the leader of the flock. The "flying geese" model experienced a revival in the 1960s when the Japanese MNEs began to relocate some of their labour-intensive activities to neighbouring economies such as Taiwan and South Korea. The "flying geese" model is now currently used by economists and other scholars to explain the industrialisation of East Asia.

3 The "flying geese" pattern has been supported by strong evidence. Numerous scholars have highlighted the decisive role played by the Japanese MNEs in the economic integration of the East Asian region (Yamamura, 1997; Hatch, 2000; Yoshihama, 1988; Oman, 1994; Hobday, 1995 \& Jones, 1997). Successive waves of Japanese (and US) FDI have helped to industrialise the former Japanese colonies of Taiwan and South Korea in the 1960s, then reached the ASEAN economies in the 1980s and finally China and Vietnam. The Japanese keiretsu and their subcontractors have regionalized their process of production and built a complex regional division of labour in East Asia.

Among the East Asian economies, South Korea, Taiwan, Hong Kong and Singapore hosted the first major wave of FDI in the 1960s. Thanks to spin-off, they managed to industrialise and started to catch up with the most advanced economies. Their domestic firms acquired new technological knowledge and management experience, which provided intangible assets necessary to transform some of them into global competitors. Major MNEs like Samsung or ACER began to emerge. Korean, Taiwanese and Singapore firms launched their own outflow of FDI in the late 1980s towards the less developed neighbouring economies (Thailand, Indonesia, Malaysia).

5 The other East Asian economies opened up later but they too were transformed by the second major wave of Japanese FDI that began to take place in the late 1980s after the endaka (the appreciation of the yen that resulted from the 1985 Plaza Accord). Their economies also began to industrialize and some local companies upgraded their technological capabilities even though none has yet managed to transform into major MNEs capable of generating substantial FDI outflows.

6 Since the mid 1990s, however, the Asian newly industrialised countries (NICs) have been in crisis. The fantastic increase in GDP per capita that these economies had experienced began to slow down and even stagnate during the last decade. The trade structure of the Asian NICs still indicates a high dependence on Japan for high-tech imports. Many analysts remain sceptical about the innovation capacities of most of the non-Japanese Asian MNEs. It is necessary now to assess to what extent the regional 
integration led by Japanese MNEs has helped to diffuse technological capacities in the region and what the newcomers like China and Vietnam can expect from joining the flock of "flying geese".

7 There is abundant evidence that the Japanese subsidiaries have transmitted technological capacities to their local subcontractors in many Asian economies. Technical blueprints and/or advice provided by technical staff are given by the Japanese MNEs to their subcontracting firms so as to improve the quality, design and conformity of the inputs. A study conducted by Rhee has shown that about $50 \%$ of South Korean firms benefited from such technology transfers from their Japanese buyers (Hobday, 1995, p.37). Japanese MNEs like Hitachi have played a similar role in the upgrading of the technological capacity of Taiwanese firms in the field of PCs and electronics (Hobday, 1995, p. 106). This transmission started in the 1960s and 1970s for Taiwan and South Korea and was extended to the ASEAN economies after the endaka. In Thailand for example, Japanese firms opened joint-ventures in the textile sector. Progressively, they lost their dominant position as Thai capital accumulated and the Thais gained the necessary technological skills. Thai firms then began to phase out progressively their Japanese partners (Yoshihara, 1988, p.31). More generally, the rising value of the yen implied a further use of locally produced parts. This forced the establishment of quality circles in local subsidiaries (Doner, 1993, p. 180), which in turn led to an improvement in local production standards and in the technological skills of the local staff. All these facts clearly indicate the existence of a diffusion of technological knowledge. The real question is, was it sufficient to create indigenous innovative capacities?

In the cases of Taiwan and Korea, some firms have managed to transform themselves into global competitors in capital-intensive and high-tech manufacturing sectors. Chaebol like Samsung, LG or Hyundai and Taiwanese firms like ACER have become internationally well-known brands. The chaebol have opened subsidiaries in North America and Europe. For the other Asian economies, no domestic firms have yet managed to reach that technological level or to open as many subsidiaries outside the East Asian region. Yet, some Thailand-based firms are important exporters of electronic goods and Malaysia has created its own car industry. These are obvious signs of industrial development that are not yet matched by any other region in the world.

\section{Assessing the performance of the most advanced flying geese: FDI outflows and indigenous innovative capabilities in Taiwan and South Korea}

9 The South Korean and Taiwanese firms have achieved astounding success. Both economies have transformed themselves from FDI recipient countries into generators of FDI outflows. Nevertheless, these achievements need to be put into perspective. All of these firms still depend on Japanese technology for high-tech inputs and machinery (Yamamura, 1997, p.88). The example of Samsung is enlightening. Samsung is considered to be an exception in South Korea for its massive investment in high tech capacities (Yamamura, 1997). It has pursued a risky and determinate policy to invest in long-term research in the US despite heavy short-term losses (Hobday, 1995, p.82). Nevertheless, it still lacks the design skills to produce key final goods in the computer industry. It is still dependent on Japanese and US imports of high-tech machinery 
(Hobday, 1995, p.85). By the end of the 1990s Samsung did not possess the R\&D capacities to go beyond incremental innovation in mature and mainstream products (Hobday, 1995, p. 87). The scope of its products was still limited in 2002, although the firm was still engaged in ambitious R\&D plans to extend its expertise and catch up with its Japanese competitors (Dicken, 2003). In his thoughtful study of technology diffusion in East Asia, Hobday concludes that, as late as the mid 1990s, the chaebol were still far behind their Japanese competitors in terms of R\&D, science, key components and advanced raw materials (Hobday, 1995, p. 90). Despite strenuous efforts to reduce their dependence on Japanese technology and South Korea being the most important R\&D spender among the Asian NICs, the structure of the bilateral Korean-Japanese trade indicates that there is an important trade deficit in high-tech products on the Korean side (Liu, 1996, p. 157). Through their interviews, Yamamura and Hatch have found that many South Korean economists and businessmen believed that the technological gap between South Korea and Japan was actually widening in 1997 (Yamamura, 1997, p. 90). The Asian crisis of 1997 did not improve this situation as the restructuring of the chaebol became the priority.

The situation of the most advanced Taiwanese firms is no different. Taiwanese leaders like ACER have acquired companies in the USA in order to improve their innovative capacities but have met little success because of the different management styles, the lack of motivation of American staff or because the best US researchers moved to other US companies (Gee, 1992, p. 37). ACER has tried to develop its brand worldwide. In 1988, as much as $60 \%$ of ACER's output was sold under its own brand but this strategy generated heavy losses. ACER had to scale down its operations and reduce the share of "own-brand" sales (Hobday, 1995, p.116). Like their South Korean competitors, Taiwanese firms still have to rely heavily on Japanese high-tech equipment and key inputs (Hobday, 1995, p. 108).

\section{Assessing the performance of the rest of the flock of flying geese: Indigenous innovative capabilities in the rest of East Asia and the notion of ersatz capitalism}

11 For the other East Asian economies, the dependency on the Japanese MNEs is much stronger. Apart from Taiwan and South Korea, Singapore is the only economy of the region, which had an ambitious education program to improve the skills of technicians and engineers (Yamamura, 1997, p. 83). But for three decades, this policy aimed mainly at providing foreign MNEs with skilled local personal rather than to support the creation of indigenous manufacturing firms (Hobday, 1995, p.141). The recent change of government policy during the late 1980s has modified this situation but the new Singapore-based MNEs are developing mainly in regional services (Nesadurai, 2003, p. 87). To pursue this strategy, they do not require the highest level of management and scientific skills. This implies that Singapore is still very much dependant upon Japanese and Western technology. The other Asian economies have not invested sufficiently to build a technological and scientific base comparable to Japan or even South Korea. The share of skilled workers among the domestic workforce of most ASEAN economies (except Singapore) was still very low by the late 1990s. In Malaysia (which is considered more advanced than Indonesia or the Philippines), this figure only reached $2.4 \%$, far 
below the take-off stage that advanced economies like Japan experienced decades before (Yamamura, 1997, p. 83).

Many indigenous firms in ASEAN economies are completely dependent on their Japanese partners, even those which are strongly protected and subsidised by their government. Within the ASEAN economies, indigenous high-tech industries able to compete on the global markets have not emerged yet despite decades of intensive industrial policies. This situation is reflected by the limited FDI outflows. Apart from Singapore, all ASEAN economies are characterized by much stronger FDI inflows than outflows (UNCTAD, 2004).

Since 1971, Malaysia has been pursuing a nationalist policy to support indigenous Malay entrepreneurs and upgrade the indigenous industrial capacities. This policy, named the New Economic Policy (NEP), forced foreign investors to develop through joint ventures with indigenous Malay. The Japanese MNEs actually adapted far better to that situation than the Western firms, which preferred to open fully owned subsidiaries (Yoshihara, 1988, p. 24). In the 1990s, the Malaysian Prime Minister Matathir Mohamad, who was one of the main designers of the NEP, eventually admitted that this highly costly policy was not reaching its original goal of creating an innovative and competitive class of Malay entrepreneurs. Rules on FDI were relaxed throughout the decade (Jones, 1997, p.114). In early 2000, the last remnants of the NEP were being progressively phased out (FT, Malaysia Report 2003). Malaysian firms are still totally dependant on MNEs in high-tech sectors. A good example of this development is the Malaysian Proton Saga carmaker, which was considered by Matathir as a key project to develop an autonomous indigenous capital-intensive industry. It was a developed under a joint-venture between the state-owned Heavy Industries Corporation and Mitsubishi Motor Corporation (MCC). Despite local content rules, MMC was able to disqualify indigenous producers by imposing strict quality control that only its traditional subcontractors could achieve (Yamamura, 1997, p.35). At the end of the process, the Japanese MNE had the effective control of the joint-venture. Proton Saga was incorporated in the regional network of MMC's subsidiaries and produced door panels for other MMC subsidiaries (Yamamura, 1997, p.35). In 2003, Proton Saga was still dependent upon foreign technology. Most analysts do not believe it capable of competing on the global market (that is, without the strong domestic barriers that protect it presently) (FT Malaysia Report 2003). It is even less probable that the Malaysian engineers alone could develop the new models of the Proton in the near future.

During the 1990s, the Indonesian authorities tried to imitate the Malaysian NEP. They adopted a strong industrial policy to support the emergence of high-tech indigenous groups in order to diminish their reliance on foreign technology (Nesadurai, 2003, p. 120). In 1989, General Suharto gave the supervision of ten state-owned companies in transport, telecoms and defence to the minister of research Dr Habibie (Jones, 1997, p. 123). This included an aeronautics firm in charge of developing a prototype for a commercial airplane, the $\mathrm{N}-250$. Most of these projects were controlled by close members of the Suharto family and ended in failure. The crisis of 1997 forced the Indonesian government to scale down its subsidies and to open further their market. The Japanese MNEs continue to be the main supplier of technology to Indonesia.

The Philippines with the small size of its economy and being one of the least developed countries of the region could not hope to build indigenous autonomous technological 
innovation capacities. They adopted many protectionist measures to pursue an importsubstitution industrialisation for decades but are still dependent upon Japanese and US technology. No Filipino firm is expected to transform itself into a global competitor in a foreseeable future.

Thailand has been a more open economy than the other large ASEAN member states. It adopted exported-oriented policies with an important reliance on FDI in the 1970s (Katzenstein, 1993, p.226). After the endaka, Thailand became one of the most important destinations of Japanese FDI in Asia. The Japanese government designed a "new aid plan" for Thailand, which provided loans and facilitated administrative procedures for the relocation of activities by Japanese firms to Thailand (Katzenstein, 1993, p. 228). The Thai conglomerates became partners in joint-ventures established by the Japanese firms which controlled the technology. An example of the Japanese technological and management control on large Thai firms is the Thai corporation Jubao Electronics. It is one of Thailand's most successful exporting firms but the patents of their products are held by the Japanese MNE Sharp which imposes the technical specifications, Jubao's production is handed to sharp for world wide distribution and it is sold under the Sharp brand (Yamamura, 1997, p. 57).

To describe the situation of the ASEAN economies, Yoshihara has developed the concept of ersatz capitalism. Despite their industrialisation and the development of large local capitalist enterprises, the ASEAN economies are not capable of innovative capabilities and of competing on a global level. This situation has turned local capitalist and entrepreneurs into rent-seekers sheltered by the state subsidies and protectionist measures or into "comprador" capitalists "acting as agent of foreign manufacturers" (Yoshihara, 1988, p.3). Neither the "crony or bureaucratic" capitalists nor the "comprador" have the ambition to transform themselves into global competitors. Their survival depends upon their local government intervention or upon foreign technology (Yoshihara, 1988, p.130). Their aim is to grab a share of the rents that can be generated in a domestic a market characterised by an opaque institutional framework.

\section{Japan, the uncontested flying geese leader}

Japan remains the uncontested technological leader of Asia. The webs that the Japanese MNEs have built through the regionalisation of their production process have generated technological spin-offs but these were far from giving the other Asian economies a sufficient scientific and technological base to develop indigenous innovation capacities in most of the high-tech sectors. The dependency of Asian economies on Japanese technology is much higher than what FDI figures could imply. Technology licensing accounts for a substantial part of the Japanese firms activities in East Asia (Yamamura, 1997). The pattern of trade clearly indicates this dependence. Japan maintains a trade surplus with all its East Asian partners (see figure 1). Among the East Asian economies, Japan has got by far the highest share of high-tech products in its total exports (Fukasaku, 1992, p.17). Japanese exports machinery and high-tech inputs to the East Asian economies, which in turn process manufactured goods and export them to the global markets. The East Asian economies finance their trade deficit with Japan, their trade surplus with the Western economies. 
Figure 1. Japan's trade surplus with its East Asian partners.

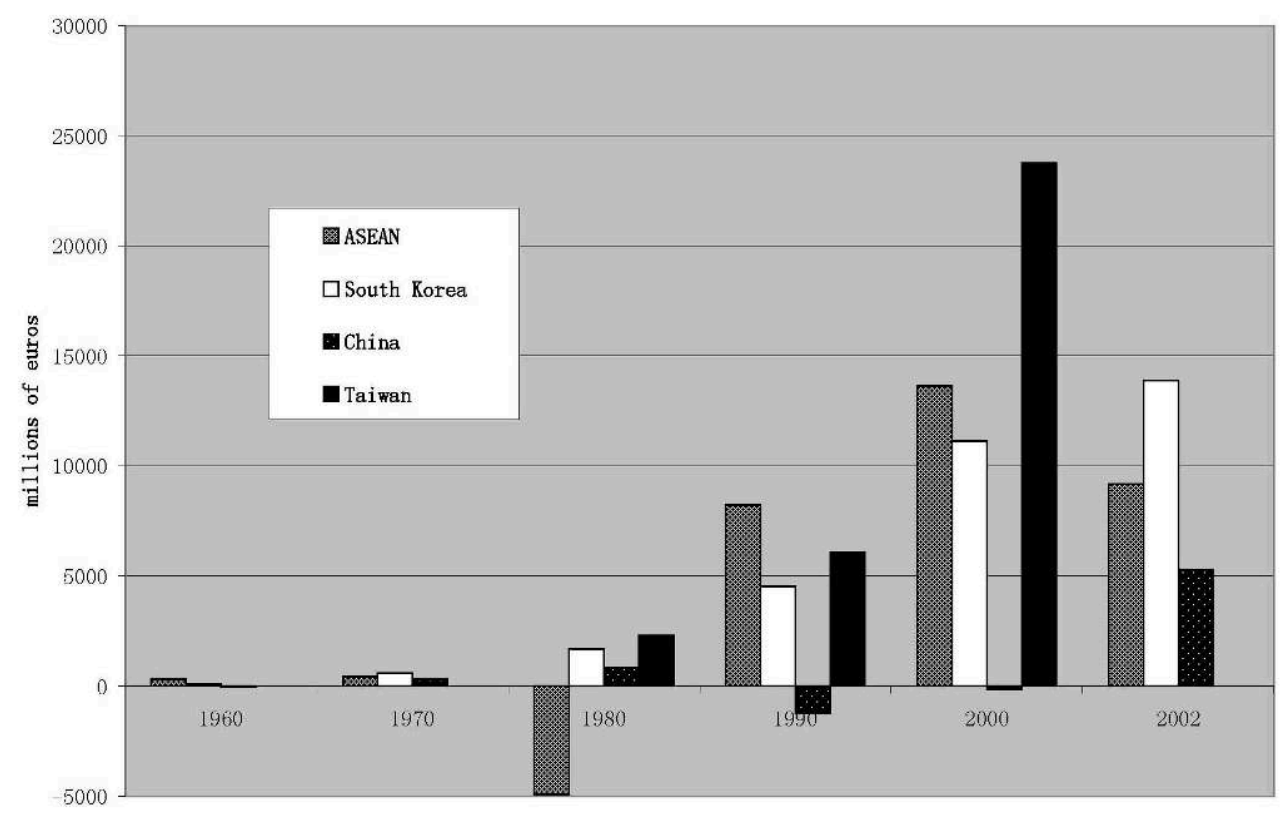

SOURCE: IMF, 2004

The level of development (and when they were touched by waves of Japanese FDI), of the indigenous firms of East Asian countries determines whether they produce more capital-intensive goods (South Korea and Taiwan) or more labour-intensive ones (ASEAN except Singapore). Indigenous entrepreneurs from Hong Kong and Singapore, thanks their traditional role as regional warehouse, have specialised in regional services. The Japanese MNEs have constituted their regional webs through FDI and licensing in which they control the technological diffusion (Yamamura, 1997, p.102). They have created a regional division of labour in which Japanese firms control most of the operations in R\&D, international management, international distribution and in advanced financial services. The R\&D facilities and the headquarters of the keiretsu are carefully maintained in Japan (Yamamura, 1997, p. 103). Japan certainly has managed to develop and to keep dynamic clusters in R\&D or "Marshallian districts" that provide external economies of scale in technological innovation. In the early 1990s, Japan ranked second in the world in scientific publications while South Korea was not even in the top 30 with less than $4 \%$ of the number of Japanese publications (Hobday, 1995, p. 64) and the gap has not been reduced during the rest of the decade (Yamamura, 1997, p. 90). The Japanese flying goose does not seem to be ready to give up its place as leader of the gaggle.

Dependence on Japanese technology is an issue for most governments in the region. Many officials and indigenous business leaders complain about the limited transfer of technology and know-how by Japanese MNEs. There are considered across East Asia to have a more reluctant attitude to the indigenisation of top management and research operations (Yamamura, 1997). Some Asian economies are trying to reduce their reliance on Japanese technology but so far, their success has been mitigated. The most obvious successes were achieved by some of the chaebol, which have managed in a narrow range of products to gain indigenous innovation capacities. Taiwanese firms most probably rank second after the chaebol but their small size and their reliance on Japanese (and US) key high-tech inputs and distribution networks means that they do 
not benefit from the same level of autonomy enjoyed by their Korean counterparts. The other East Asian economies have never really tried (Singapore, Thailand or Hong Kong) to build their own technological innovative capacities or have clearly failed (Malaysia's NEP and Indonesia Habibie's high-tech projects). Singapore, Hong Kong and Taiwan are the three economies that managed best to keep alternatives sources of technology by hosting many Western MNEs but this has not reduced the reliance on foreign technology.

\section{The optimistic scenario: China breaks away from the "flying geese" pattern}

21 Yet, some analysts claim that China could experience a more favourable situation than its ASEAN counterparts because of the sheer size of its economy. Chinese enterprises would break away from the traditional East Asian technological dependence vis-à-vis Japan and would escape the fate of ersatz capitalism. This optimistic scenario is usually based on a series of factors. Firstly, just like in the Korean case, the large flows of FDI coming to China will generate spin-offs and ultimately provide the Chinese firms with the intangible assets in technology and management they need in order to compete with world-class multinational enterprises (MNEs). Secondly, the large Chinese market will give domestic firm a strong base from which to expand on world markets after having benefited from economies of scale and learning by doing. Thirdly, thanks to its potentially huge domestic market, the bargaining position of the Chinese government is stronger in imposing technological transfers by MNEs investing in China, thereby imposing better conditions for the Chinese emerging leaders in industries and services. Fourthly, even disregarding this more advantageous bargaining position, many MNEs will prefer to invest R\&D facilities in China to improve "time to market" and to be able to react quicker to a volatile demand keen on new differentiated products (Kim \& Lee, 2004, p.16). Indeed, some MNEs have recently established R\&D centres for product development aimed at the Chinese market (Chen, 2004, p.13). Finally, MNEs will continue to be attracted by the cheap price and availability of high-quality Chinese engineers (Chen, 2004, p.13). No other developing Asian economies can offer such a large pool of trained scientists. This enabled world class firms like IBM, Microsoft and Intel to engage in basic technology research in China in collaboration with Chinese universities and state-funded research institutes (Chen, 2004, p. 14).

These developments have generated many fears from neighbouring economies such as Taiwan and Korea which are afraid of being technologically leapfrogged by China (Chen, 2004, p.15 \& Nam, 2004, p.22). Korean economists believe that China's technological gap behind Korea is shrinking. Some estimate this gap to be around three to five years for many products (Nam, 2004, p. 22). One of the strongest views on the matter was expressed by South Korea's national science and technology committee. It claimed in December 2003 that the country had a technological gap of only 1.7 years over China and that it would be closed within five years (FT, 21/12/2003).

If such a gap is actually being closed by Chinese firms, China would have achieved a better performance than any other Asian economies. With such an ability to benefit from technological spin-off, Chinese firms could even hope to avoid the fate of technological dependency vis-à-vis Japan endured by the other Asian "geese". Numerous Chinese firms would transform themselves into global MNEs, capable not 
only of competing with the firms of the intermediate economies, but even with the Japanese keiretsu. Chinese firms would become major foreign investors. The Chinese economy would break the traditional "flying geese pattern" and challenge Japan in its economic leadership of East Asia.

The following sections will demonstrate that the optimistic scenario of such a phenomenal leapfrog by China does not resist a careful analysis of both FDI inflows structure and the transformation of the socio-institutional framework of the Chinese economy since the reforms were launched in 1978. Therefore, it will show that the possibility of Chinese global competitors emerging, although not impossible, is much more remote than some analysts claim. Japanese firms and even some Asian firms still enjoy a considerable advance in the capacity to innovate and to operate internationally. China is unlikely to take over the leadership of the "flying geese".

\section{An assessment of the current situation of Chinese firms and their acquisition of ownership-specific advantages}

In order to determine the possibilities of China's reversing the "flying geese", numerous Chinese firms would have to transform themselves into global competitors capable of expanding abroad. This is different from enjoying a high trade surplus and hosting competitive firms, two achievements of the Chinese economy. What distinguishes the advanced OECD economies like Japan from the industrialised developing countries is the existence, across most sectors of activity, of national firms benefiting from what Dunning calls "ownership-specific advantages" or "Oadvantages" (Dunning, 1996, p.79). These O-advantages are the intangible assets that constitute barriers to entry in a particular sector of activity (Dunning, 1996, p. 81). They include notably operating at a sufficient scale to minimize costs (the so-called "minimum efficiency size"), management know-how, innovative capabilities, goodwill or privileged credit access. These intangible assets give enterprises a competitive edge on the world markets and enable them to invest directly abroad and to transform themselves into MNEs. The enterprises that do not possess such O-advantages are stuck into activities characterized by low barriers to entry and therefore low profit margins. These are most often mature industries abandoned by the most efficient MNEs.

The crucial question for the future role that the Chinese economy could play in the East Asia and on global markets is to determine if the Chinese firms could acquire Oadvantages and become global competitors in the activities characterised by high barriers to entry, that is mostly the technological-intensive sectors.

If this is the case, the Chinese economy could soon compete with Japan as the driving force in the integration of the East Asian economy. Chinese emerging MNEs could follow the path of their Japanese counterparts in establishing a complex regional division of labour in East Asia. If Chinese firms cannot acquire such advantages, they are bound to join the pack of East Asian countries that participate in the regional specialisation set up by the Japanese MNEs and Japanese institutions like the MITI or Keidaren. In that case, Japan would remain the leader of the so-called "flying geese" economies. China could only hope to play the role of an auxiliary driving force in the East Asian economy, lacking the innovative and management capabilities to lead the 
flying geese. Furthermore, without strong national champions that could compete globally in industries and services, China's entrepreneurial class could resign itself to playing the comprador capitalist specialised in the activities subcontracted by the foreign MNEs or sheltered into state-protected sectors. China would then resemble to the ASEAN economies and adopt what Yoshihara has called an "ersatz capitalism" model (Yoshihara, 1988).

Considering the arguments that have just been examined, it is necessary to assess the current situation and prospects of Chinese firms in the acquisition process of 0 advantages. Despite the fact that Chinese statistics are scarce and are not always accurate for that purpose, some figures can provide worthwhile material for such assessment.

\section{How to measure the extent of 0 -advantages acquisition by Chinese firms?}

Firstly, if Chinese firms are now acquiring O-advantages, they should withstand successfully MNEs competition and begin to export around world markets and ultimately to invest abroad in activities that are intensive in capital and technology. This would imply that FDI constitutes an important share of investments made by Chinese firms. FDI outflows are therefore a good indicator of this acquisition of Oadvantages. Secondly, one must also analyse the FDI inflows as they might reflect the lack of competitiveness of Chinese firms. One can naturally object that substantial FDI inflows occur in OECD countries and they do not reflect an absence of strong global competitors in these economies. However if in a given country, FDI inflows constitute a substantial part of gross domestic investment and, at the same time, dominate massively the FDI outflows, it probably reflects the inability of local firms from this country to acquire O-advantage in most of the sectors intensive in capital and technology. Such relatively massive FDI inflows would indicate a high probability of foreign MNEs taking over local firms in these sectors. From these propositions, a comparative analysis of the respective FDI outflows and inflows from China and from other Asian economies can contribute to reveal the extent of the catching up achieved by Chinese firms over their Asian counterparts.

To acquire O-advantage for a firm is notably to be able to manage successfully large scale operations. This requires the firm to reach the given current minimal efficient size. This induces that one has to compare the size of the Chinese firms with their global competitors in sectors characterized by important economies of scale. However, reaching a size in terms of assets is a necessary but not a sufficient condition for the acquisition of O-advantages. For a firm based in a developing economy (especially in former centrally-planned economies), a large size in terms of assets does not mean necessarily that the later has adopted modern management and production techniques. It could simply be the result of an extensive growth (based on quantitative increase of the various factors of production) while firms that are in the process of acquiring Oadvantages have to pursue an intensive growth (based on a more efficient combination and use of these factors of production). Therefore in order to create a clearer picture of the extent of O-advantages acquisition by the Chinese firms that have reached the minimal efficient size, one must observe other elements such as the capital intensity and the return on assets. One could argue that capital intensity is not a relevant 
variable in the case of China. Indeed if the Chinese labour costs are much lower than in other industrialized countries, why would efficient firms not choose a more labourintensive technology? This is to forget that sectors where O-advantages and barriers to entry exist do not allow an ample choice of substitution between labour and capital. In capital and technology intensive sectors, the production processes are characterised by specific machine-tools, robots, electronics that require skilled labour. This impedes substitution between labour and capital. Ample evidence is available if one looks at the production process of MNEs operating in China. Thus, relative capital intensity is still a relevant variable to see if the large Chinese firms are upgrading their technological capabilities.

\section{Comparing the performance of Chinese firms and their global competitors}

31 If Chinese firms are now acquiring O-advantages, they should withstand successfully MNEs competition, begin to export around world markets and ultimately invest abroad in activities that are intensive in capital and technology. On the contrary, looking at FDI flows and comparing the performance of Chinese firms with those of the MNEs' subsidiaries located in China brings to light worrying trends.

\section{FDI inward flows and investment}

China has attracted more FDI relatively to its GDP than large emerging economies and East Asian economies. When FDI inflows are compared with fixed assets investments, the dependence upon foreign investment is even more striking see figure 2). Countries that have shown a similar or greater degree of dependence than China were either unable to develop their own technological base or faced a strong recession which induced a drastic fall in domestic investment. Malaysia is the typical example of an East Asian economy that has not been able to develop innovation capabilities and to transform indigenous firms into global competitors Yamamura, 1997, p.35 \& FT Malaysia Report, 2003). Thailand has reached the Chinese level of dependency only after facing a massive financial crisis involving devaluation and capital flight Thailand after 1997 on figure 2). The two most successful economies that managed to catch up the advanced OECD economies - Japan and South Korea - have never experienced that level of dependency. After the 1997 crisis, South Korea had to open up its capital markets and to increase its level of dependency. This period was a very difficult one for the South Korean firms which were subject to painful restructurings. However, when the Korean economy began this rationalisation of production capacities, it has been reducing its dependency on FDI inflows see figure 2). 
Figure 2. FDI inflows as a percentage of gross capital formation 1995-2003 in China, Asian and other emerging economies.

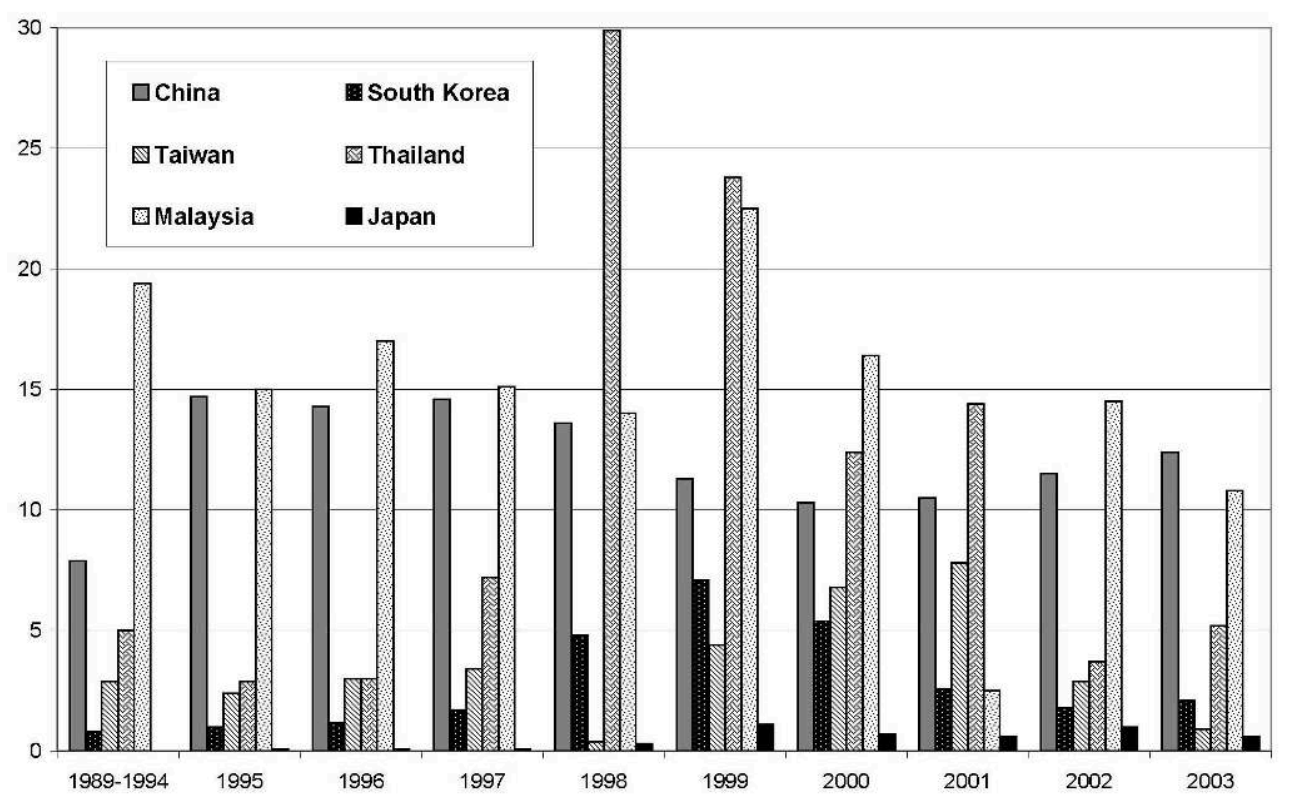

SOURCE: UNCTAD 2000-2004 despite the fact that Chinese domestic investments have beaten historical records. Chinese investments have been over $40 \%$ of the GDP in the 2000s Lemoine, 2004, p.63). Never such levels had been observed in any other economy during the $20^{\text {th }}$ century. Exceptionally strong investing economies like Stalinist Soviet Union, post-war Japan or South Korea in the 1970s managed to reach a ratio of gross capital formation over GDP of around 30 to 35\% (sources: Davies, 1998, p. 40; Gregory, 1990, p. 124; Nakamura, 1995, p. 210; Lanzarotti, 1992, p. 31; Maddison, 1995, p.144). which are modernizing their equipments. However, a far less brilliant picture emerges once one looks into other indicators of the Chinese economy. The reasons behind this high level of investment are widely known. Firstly, credit for State-Owned Enterprise (SOEs) is extremely cheap which encourages fixed assets investment. This is due to the Chinese banking system that organises its loans on political and social considerations rather than on standard capitalist criteria. Despite this surge in domestic investment, the industrial output of MNEs in China is still rising faster than those of Chinese firms. This means that the productivity of capital is extremely low for Chinese firms (or that Chinese investment have an unlikely strong bias in favour of services). Can one apply the argument that Paul Krugman has developed over the growth of the ASEAN economies to China (Krugman, 1994, p. 68)? It would imply that the growth of Chinese firms is more extensive (using more inputs) than intensive (combining better the inputs so as to increase long term productivity). The World Bank and the IMF have produced statistics that seem to confirm this view. The growth of Chinese output is mainly due to a high degree of mobilization of inputs, labour and capital, and not to an improvement of total factor productivity (the combined effect of these inputs). As total factor productivity increase is a proxy for technological and managerial know-how upgrading, provided these figures are accurate, the impact of technological and 
management upgrading on the Chinese output growth have actually been decreasing over these last 15 years (Tseng \& Rodlauer, 2003).

The OECD has estimated that during the 1990s most of the total productivity gains were made by foreign firms (OECD, 2001). Its assessment of the innovative capabilities of Chinese firm is pessimistic (OECD, 2002). This is confirmed by the rising share of MNEs in China's trade. MNEs are importing faster than Chinese firms and faster than the industrial output. Furthermore the main imports of MNEs are high-tech inputs such as integrated circuits, plastics, electronic components, and machinery (MOFTEC, 2002, p. 38). It means that Chinese subcontractors have not been able to upgrade their technology and take control of a larger part of the production process. Qualitative studies show that MNEs are demanding their traditional non-Chinese subcontractor to follow them and to set up subsidiaries in China rather than to depend upon Chinese subcontractors which cannot always reach the international standards in terms of quality (Taylor, 2000, p. 139; Kim \& Lee, 2004, p. 7; Nam, 2004, p. 14).

The share of Chinese exports produced by MNEs has been rising until the mid 1990s when it stabilized above the $50 \%$ (see figure 3). Huang has shown that Asian newly industrialised countries (NICs) never had to rely so heavily on MNEs for their exports. At their highest peak, MNEs were responsible for $20.6 \%$ of Taiwanese manufactured exports in 1980 and 29\% of Indonesian manufactured exports in 1995 (Huang, 2003, p. 32). Looking at China's export structure, it is clearly visible that MNEs dominate the exports which are intensive in technology and capital. Already in 1995, MNEs accounted for more than $83 \%$ of the electronic and electric appliances (Huang, 2003, p. 32) While textile accounts for more than $25 \%$ of Chinese exports (Dickson, 2003, p. 198), MNEs located in China mostly export components, household appliance and machinery. Textile products are not even among the most important export values of MNEs (MOFTEC, 2002, p. 36).

Figure 3. The impact of MNEs on China's imports and exports.

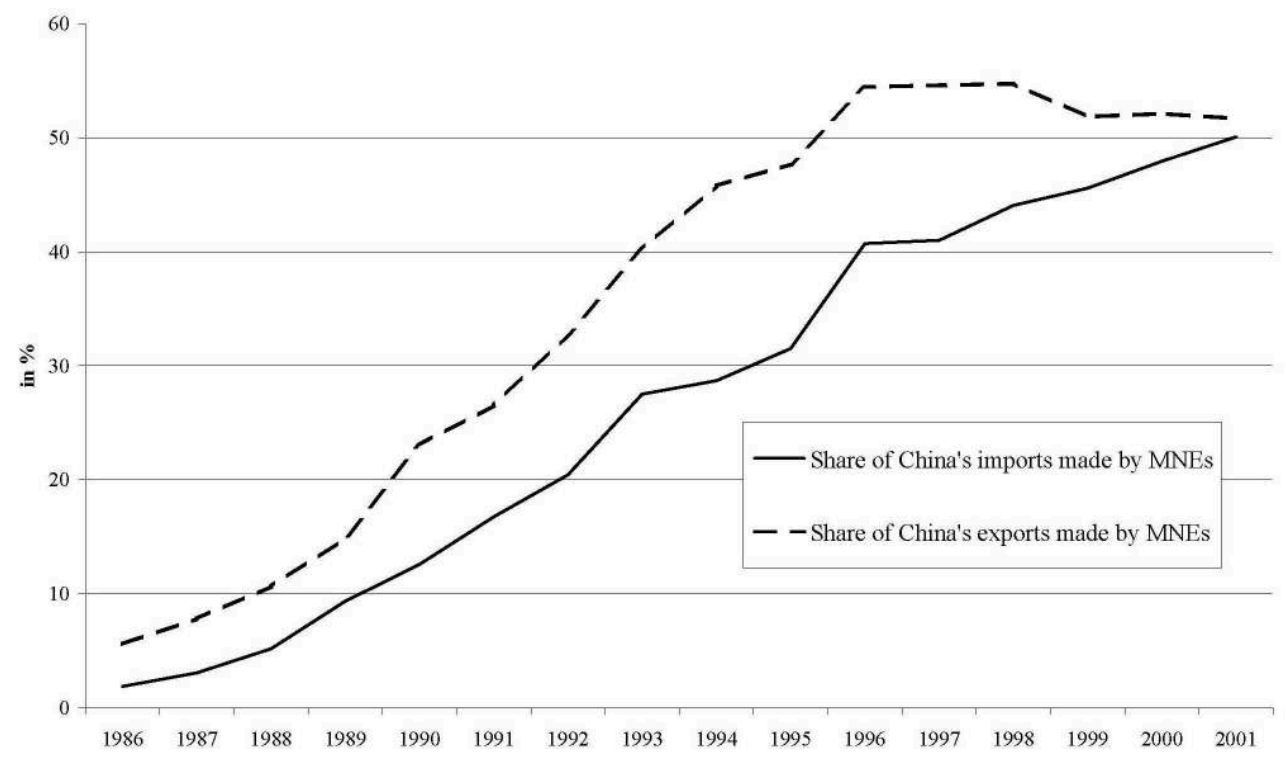

SOURCE: MOFTEC, 2002 


\section{Outward FDI flows and the acquisition of 0 -advantages} this share has been shrinking these last two years (see figure 4). It is still far lower than the share currently reached by the Asian NICs. China's current data are not more impressive when compared to South Korea's data for the period 1986-1990 (when the Korean chaebol were turning into major global competitors). For this period, the average share of outward FDI in gross capital formation stood at $1.4 \%$ compared to an average of $0.76 \%$ for China from 1998 to 2002 . The exceptional performance of Taiwan in terms of FDI outflows also reveals a worrying trend for mainland China. Most of Taiwan's FDI flows are directed to China, reflecting the O-advantages held by Taiwanese firms over their mainland competitors.

Figure 4. FDI outflows as a percentage of gross fixed capital formation 1995-2003 in China and other Asian or emerging economies.

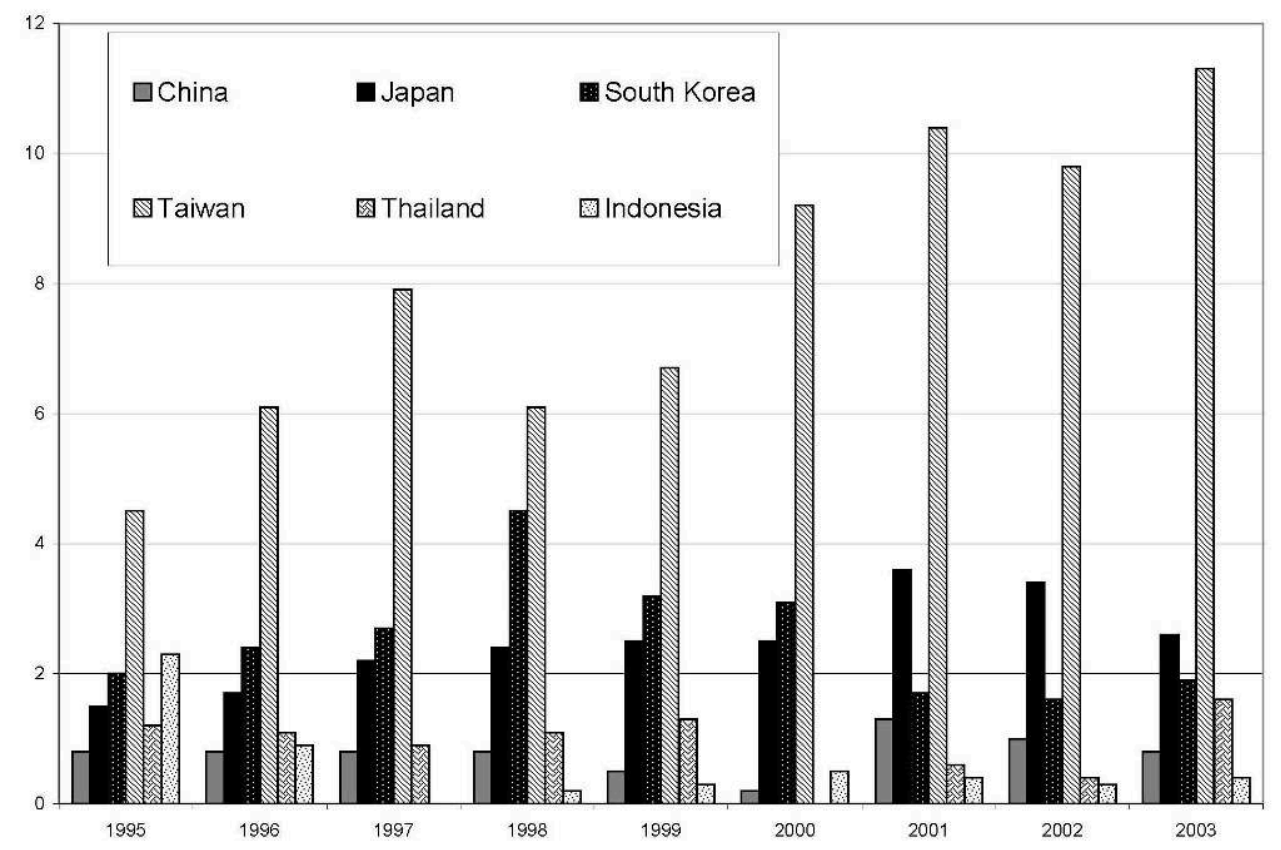

SOURCE: UNCTAD 2000-2004 
dhe Chinese firms are not always acting on their own. Their expansion abroad is sponsored, sometime driven, by the central government if these firms belong to its list of national champions (see below section 3.3) (APCO, 2003, p.50). Are these government-sponsored FDI outflows based on long-term profitability or are they overambitious schemes created for political prestige? The take-over of foreign firms is seen by the Chinese government and Chinese firms as a mean to acquire technology. In 2004, China National Blue Star Group projected to buy a majority stake in Ssangyong Motor, South Korea's fourth-largest carmaker. In 2002, BOE Technology of China took over the flat panel display-making arm of South Korea's Hynix Semiconductor. Gee has shown that this strategy produced disappointing results in the case of Taiwan. Taiwanese leaders like ACER have acquired companies in the USA in order to improve their innovative capacities but have met little success because of the different management styles, the lack of motivation of American staff or because the best US researchers moved to other US companies (Gee, 1992, p.37). Chinese overseas expansion could create more debt than opportunities of upgrading technological and management capabilities. The extent of government support behind the FDI outflows questions the fact that these flows reflect a real ability by Chinese firms to open subsidiaries on their own.

41 Thirdly, some of the biggest Chinese investors abroad are in the mining and oil industries. Most of their FDI does not reflect O-advantages on the global market but the will from the Chinese government to insure access to strategic raw materials. For example, in 2003, China National Offshore Oil Corporation has invested about A\$ 1 billion in Australia's Gorgon gas field. However, the effective operator of the gas field is Chevron Texaco and no technological transfer is programmed (FT, 24/10/2003). Again this year, Chinese FDI to control Indonesia oilfields followed the same logic.

Fourthly, one must not forget that in 2001 more than 55\% of Chinese FDI outflows ended in Hong-Kong (APCO, 2003, p.50). A substantial part of these flows are not generated by firm possessing O-advantages but by SOEs investing in Hong-Kong for other purposes than launching an economic activity. Some investments can be politically motivated to create stronger links between the territory and the mainland. For example, the largest "foreign" investor in Hong-Kong is the China International Trust Investment Corporation whose chairman is Larry Yung, the son of China's vice president (Monde Diplomatique, 2003 (06), p.11). Other Chinese FDI outflows are transiting by Hong-Kong to be transformed into FDI originating from Hong Kong to the mainland. Chinese capital is thereby transformed into "foreign" capital, the latter benefiting from the same private property rights than the genuine FDI flows to the mainland. This transformation is particularly useful for the managers of SOEs who misappropriate the state assets of their company. According to various analysts, this phenomenon accounts for between 7 to $25 \%$ of all Chinese FDI inward flows (Huang, 2003, p. 38).

43 This mechanism of "roundtrip" FDI generates ambiguous results on the conclusions reached in the analysis so far. The positive aspect for Chinese firms is that the Chinese investors are doing much better relatively to foreign investors in China than official statistics suggest. As some Chinese capitalists are channelling capital through HongKong and off-shore centre like the Virgin Islands to benefit from better property rights, it means that some Chinese investors might create new private firms and provide them with liquidity. Nevertheless, the lack of disaggregated figures forbids any conclusion on 
the precise nature of roundtrip FDI. Roundtrip FDI can also end in Guangdong province's real estates or in other speculative activities. The negative aspect is of course that many Chinese foreign investors do not possess O-advantages when they invest in Hong-Kong.

One certain positive progress lies in the capacities that some large Chinese firms have acquired thanks to the huge chinese public works. These firms can now provide services in construction and utilities for large third world countries. It has been the case for the reconstruction of Alger's airport or for China Telecom expansion in Indonesia (FT, 24/09/2003). Nevertheless, these examples show that Chinese firms are still far from the upper segment of the world market; that is gaining access to OECD public works and utilities.

Despite this bleak general outlook of the overall performance of Chinese firms, it is still possible than a handful of them possess $\mathrm{O}$-advantages. As it has been mentioned before, operating at a sufficient size is essential in activities characterised by high barriers to entry which often incur high fixed costs and therefore economies of scale. The next section examine the size and the performance of the largest Chinese firms compared to those of their global competitors.

\section{Are the largest Chinese firms acquiring 0-advantages?}

In 2001, the year China formally joins the WTO, 11 Chinese firms belonged to the top 500 global firms in terms of sales (Fortune, 2002, F-27). This performance has only been matched by South Korea, while only two firms of the top 500 were based in other ASEAN countries or in Taiwan. However, it would be difficult to claim that any could qualify as MNEs possessing O-advantages. They are in the sectors of utilities, oil refining and banking. Two companies, Sinochem and Cofco, were in trading. These eleven firms are SOEs who operate almost exclusively on their domestic market.

Figure 5. The return on assets of the largest Chinese and Korean firms in 2001 (in \%).

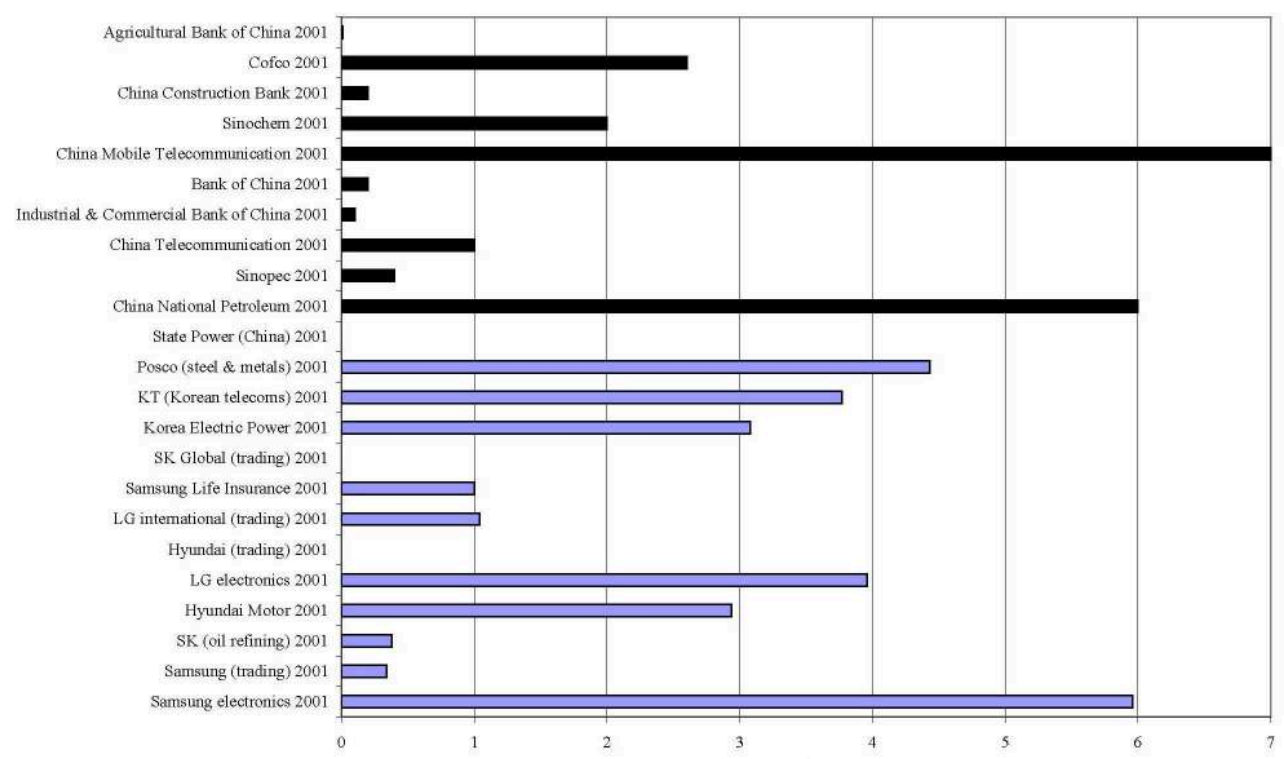

SOURCE: FORTUNE 500, 2002 
By looking at the return on assets, six of them are doing far worse than the average of their largest global competitors (Fortune, 2002). These figures are not surprising for some activities. It is widely known that the performance of the largest Chinese stateowned banks (often referred as the "big four") is appalling. By international standards, the "big four" are considered to be bankrupt and have been bailed out by the central government three times in five years (CEPII, 2004 \& the Economist, 20001,19/05/01 \& Le Monde, 2003, 08/08/03). The profitability of the two oil refining companies is less catastrophic but they are visibly overstaffed compared to their global competitors (see figure 6). These two firms own too many refineries operating at a too small scale to be cost-efficient (Nolan, 2002, p.50). Their distribution networks are lagging far behind those of their global counterparts. Finally, both companies are not strong in the highvalue added segments of the oil products (Nolan, 2002, p.51). In terms of R\&D, none of these eleven firms belongs to the 300 biggest spenders (Nolan, 2002, p. 47).

Figure 6. The capital intensity of the largest Chinese and South Korean firms in 2001: the amount of assets per employee of the firm compared to the average of its industry within the global top $\mathbf{5 0 0}$ (in \%).

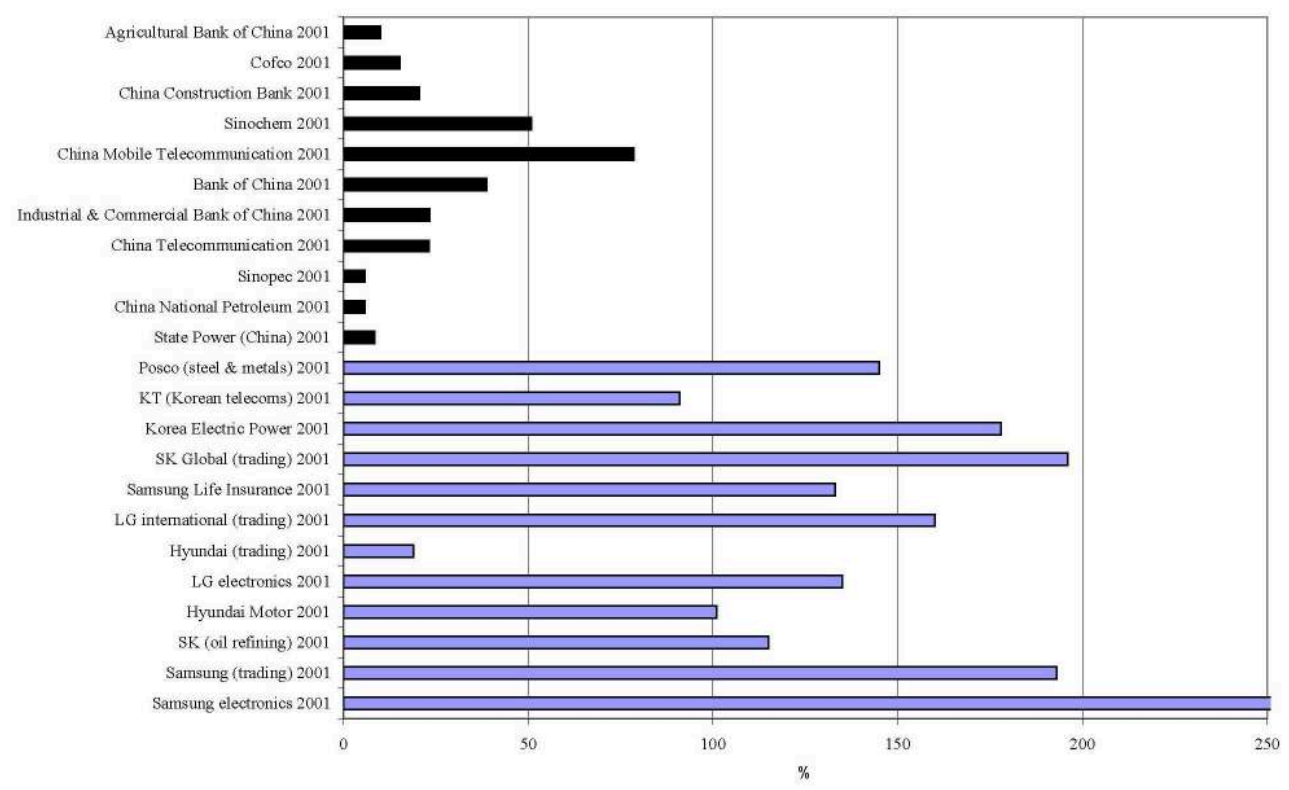

SOURCE: FORTUNE 500, 2002

The satisfactory profitability of the Chinese firms in telecoms and trading can probably be better explained by the lack of competition on the Chinese domestic market in these activities than by a mastering of technology and management. In 2001, these activities are still closed to foreign investors and the WTO accession protocol signed by China has scheduled a progressive liberalisation that will not be completed before 2004-2006 (Beseler, 2002, p.6). The dominant position of these giant firms on their non contestable domestic markets enables them to achieve high profit margins but it does not mean per se that they have yet acquired O-advantage.

The Chinese champions in other activities are still too small to make it in the global top 500 in terms of sales. However by any standards, there are far below their global competitors in terms of sales, R\&D spending. Many of them are losing domestic market share to foreign competitors. Nolan has outlined such weaknesses in the aerospace, 
pharmaceuticals, electrical goods, automobile, coal and steel industries (Nolan, 2002, pp.48-56). Even successful known Chinese brands like Haier, Kelon in the white good industries and Lenovo (formerly Legend) in computers are small in terms of sales compared to their global competitors. In 1998, Kelon was still ten times smaller than a mid-size US firms like Maytag (Huang, 2003, p.195). In these activities, Chinese firms have not yet managed to upgrade their products and are still stuck in the lower segment of the markets characterised by lower profit margins (Nolan, 2002, pp.48-56; Huang, 2003, p. 196).

Overall, the performance of the largest Chinese firms is much worse than the performance of their largest global competitors which originate mainly from Japan, North America and Europe. But even if one looks at global firms from a newly industrialised Asian economy like South Korea, the difference of performance is also striking. The comparison of capital intensity reveals that Chinese firms are far more overstaffed than their Korean competitors (see figure 6). Two third of the South Korean chaebol have a higher return than the average of their industry, most of them in capital or technology intensive sectors (Fortune, 2002). On the poor performing last third, three of the four companies are in the trading industries which cannot be considered as a technology intensive industry. In terms of capital intensity, 9 of the 12 chaebol belonging to the Fortune 500 are more capital intensive than the average of their largest competitors while it is just the opposite for all the 11 Chinese firms which are far more labour-intensive than the average of their industry (see figure 6).

One could always argue that Chinese firms are only beginning their transformation into global competitors benefiting from O-advantages. Therefore, a relevant comparison should not look at the current figures of the Japanese and Korean global firms but at the figures when they first joined the world largest firms. Nevertheless, even with these figures, the performance of the Chinese largest is far from impressive. Japanese keiretsu in the early 1960s, when they started their international expansion were in a much more favourable situation that Chinese firms today. They had higher returns on assets than most of the Chinese largest firms of 2001 (see figure 7). Seven out of the twelve Japanese largest firms were more capital intensive than the average of the firms of their industry belonging to the global top 500. The remaining five were not far behind except for the oil industry (see figure 8). This conclusion also holds for most of the Korean chaebol of the mid 1980s (see figures $7 \&$ 8). On a macroeconomic level, the share of outward FDI flows in the gross domestic gross capital formation is $75 \%$ higher in the Korean economy of the late 1980s that in the Chinese economy of 2003. The Korean firms of 1985 were therefore, on average, far more advanced in the internationalisation of their operations than the Chinese champions of the 2000s. 
Figure 7. The return on assets of the largest Chinese firms in 2001, Japanese firms in 1961 and Korean firms in 1985 (in \%).

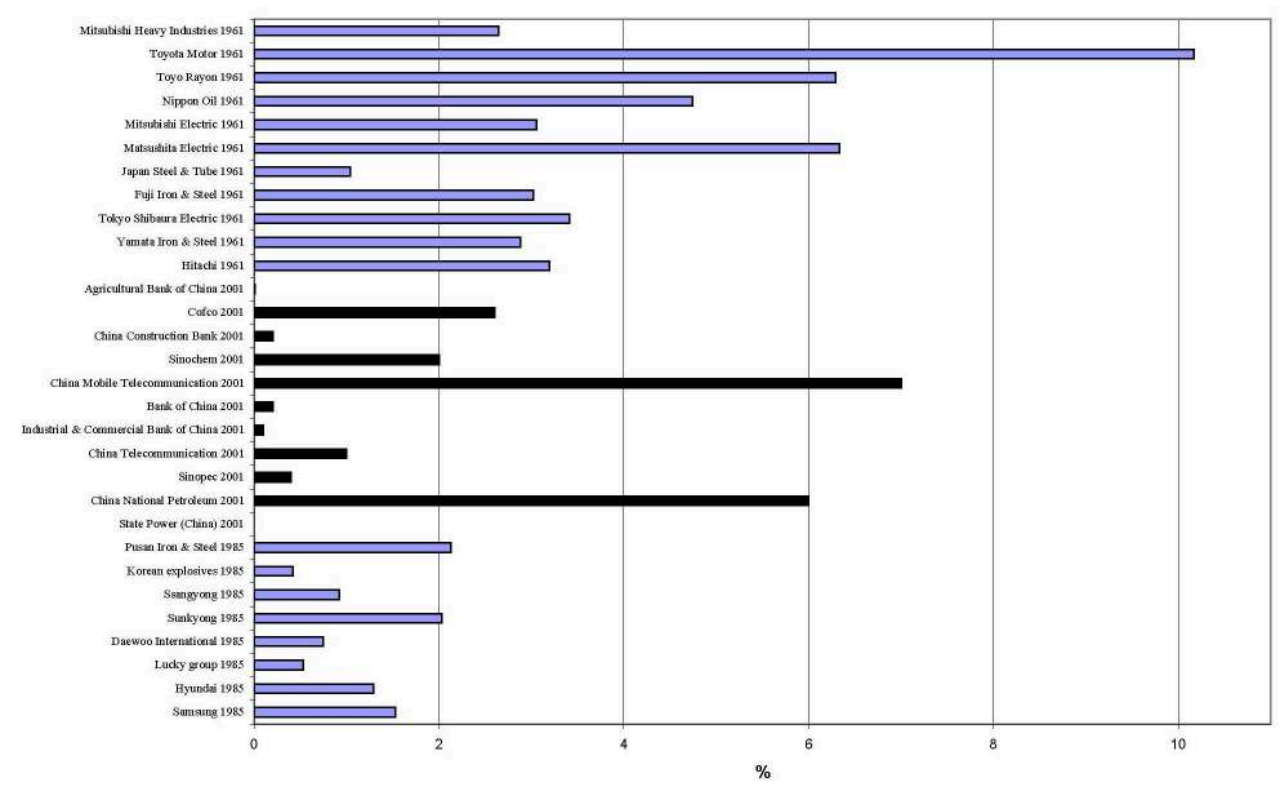

SOURCE: FORTUNE 500, 1962-2002

Figure 8. The capital intensity of the largest Chinese firms in 2001, Japanese firms in 1961 and Korean firms in 1985: the amount of assets per employee of the firm compared to the average of its industry (in \%).

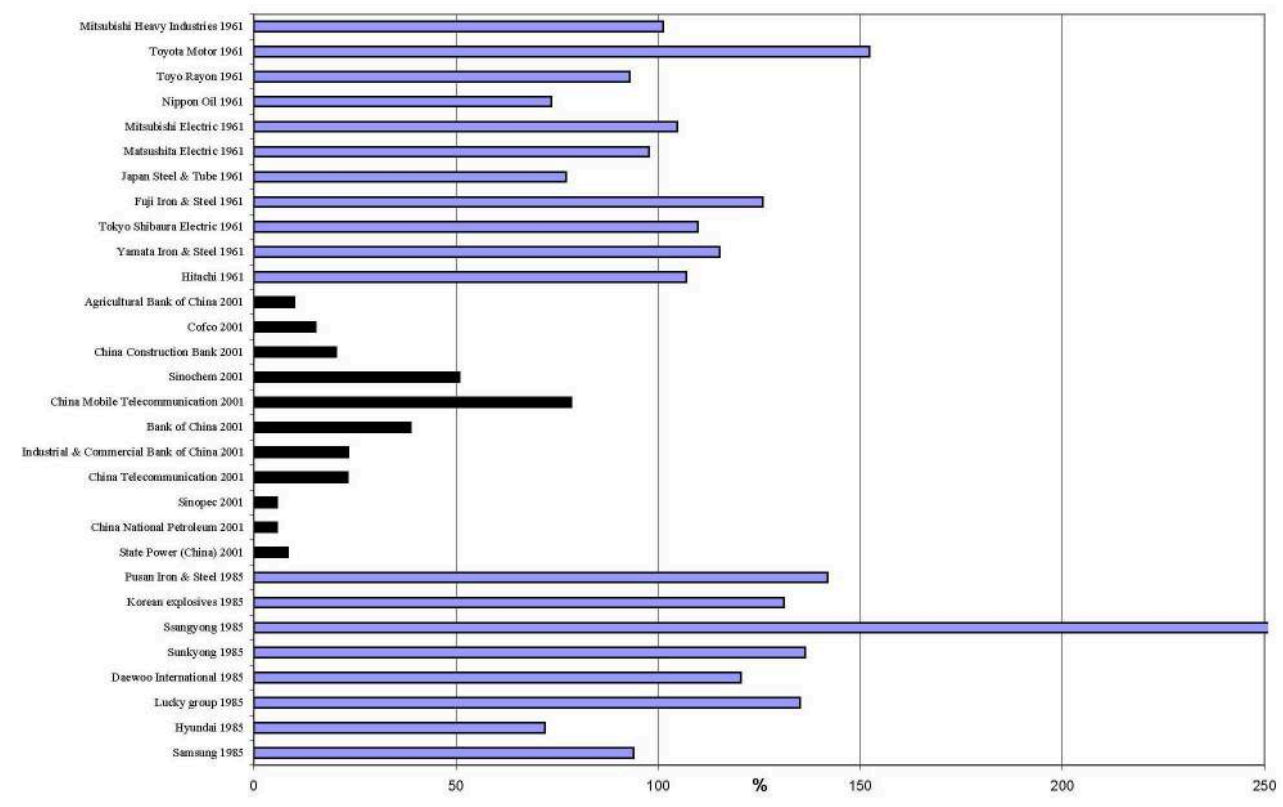

SOURCE: FORTUNE 500, 1962-2002

\section{The prospects of the largest Chinese firms}

52 The preceding section has pointed out that, at best, only a handful of Chinese firms can claim to be close to acquiring O-advantages and not in the most technology-intensive 
activities. A comparison with the past situations of Japanese keiretsu and Korean chaebol does not fit with the optimistic scenario over China's economic development described in the introduction. However, some could argue that Chinese firms are only in the early stage of the acquisition of O-advantages. They would be in a similar situation than the one once experienced by the large firms of relatively advanced East Asian economies such as South Korea.

\section{Can the largest Chinese firms follow the footsteps of the keiretsu and the chaebol?}

In order to see if the largest Chinese firms can hope to meet the same success than their Korean competitors, it is necessary to study in minute detail the emergence of South Korea's chaebol. Some of the evidence corroborates the spin-off effects generated by FDI that has been described above. During the 1960s, the government encouraged export-oriented FDI to restore their trade deficit problem and to acquire technological capabilities. Exports of transistors started in 1962 made by companies such as Motorola or Signaletics. They were followed by Japanese-Korean joint ventures like SamsungSanyo, Toshiba and Goldstar-Alps electronics. The government offered incentives and privileges to MNEs such as fiscal exemptions (Hobday, 1995, p.58). During the 1960s, foreign firms dominated the sectors in which they were present. Korean firms played the role of subcontractors for the foreign MNEs. Thanks to technological spin-off, they progressively upgraded their technological capabilities, taking control of a larger part of the production chain. As early as the 1970s, the Korean firms were moving from providing simple components to their foreign contractors to the complete production of low-tech consumer goods (Hobday, 1995, p.59). They developed their own brands and R\&D in the 1980s and by the 1990s, some had become successful global competitors such as Samsung and LG. But this would be a very narrow view of the diffusion of technology and managerial know-how in South Korea.

According to the optimists, some Chinese firms are now well into the second stage in which they are upgrading their technological capabilities and moving from providing simple components to their foreign contractors to the complete production of low-tech consumer goods. Some analysts even believe that thanks to its size and the massive FDI inflows, China could leapfrog the Asian NICs (Chen, 2004, p.15; Nam, 2004, p.22; The Economist, 25/08/2001, p.57). Despite obvious cases of technological upgrading by Chinese firms, it would be difficult to follow the steps of the chaebol. A deeper analysis of the transformation of some chaebol into MNEs shows that it has necessitated more conditions than simply the presence of MNEs and subcontracting agreements.

Firstly, the international environment proved decisive in the acquisition of foreign technology by the chaebol and in gaining access on foreign markets. Because of the Korean War and the Cold War, the successive American administrations gave South Korea a preferential economic treatment. They provided a very important aid package. From 1953 to 1975, US aid to South Korea amounted to \$13 billions (Jones, 1997, p. 69). This aid package helped to relieve the serious post-war food shortages and to finance the land reform but it also generated long-lasting effects. US financial flows provided South Korea with foreign currency during the first decade after the war at a time when there were virtually no Korean exports. During this period, US aid funds financed $70 \%$ of all imports and amounted to $80 \%$ of the fixed capital investment (Lanzarotti, 1992, p. 
36). US military aid also enabled South Korea to avoid paying for its defence costs until the 1970s. This saving certainly helped the government to increase the level of public spending on education, which rose from less than $3 \%$ at the end of the war to $22 \%$ in 1987 (Hobday, 1995, p.54). Military co-operation also gave the young Koreans drafted into military duty a valuable technical training. The Korean army built infrastructure thanks to American technical assistance (Lanzarotti, 1992, p. 40). This proved crucial in an economy crippled by a shortage of engineers and trained technicians (Hobday, 1995, p.53). Lastly, the US administrations helped the South Korean economy by providing a privileged access to its domestic market (Jones, 1997, p.79). Until the 1980s, successive US administrations were cautious not to block imports from South Korea. The US administrations also favoured the integration of South Korea in the world economic community as a member of the GATT and later of the OECD.

Secondly, the chaebol developed under strong state protection as the successive South Korean governments were strongly influenced by the Japanese model of industrial policy and management (Hobday, 1995, p.22). Under the dictatorial rule of General Park, an Economic Planning Board was established based on the model of the Japanese MITI. The Ministry of Commerce and the Ministry of Finance designed jointly the industrial policy based on a co-management system between the state and the private sector (Jones, 1997, p.71). In 1973, the government decided to encourage a shift from light industry such as footwear and textile to capital-intensive industries. The Heavy and Chemical Industry Plan was launched and resulted in the emergence of the chaebol conglomerates in strategic industries: iron and steel, machinery, non-ferrous metals, electronics, shipbuilding, automobile and petrochemicals (Jones, 1997, p. 72).

In the late 1970s and during the 1980s, the government protected some sectors by restricting entry to foreign firms and forcing them to enter the domestic market through joint-ventures with the major local firms such as Hyundai, Daewoo, Goldstar and Samsung. They also encouraged Japanese firms to disinvest by terminating their tax break policy for foreign investors. They developed a negative list of sectors closed to foreign firms on national security grounds. Foreign firms like the Japanese NEC were forced out of their former joint-ventures and had to close down their subsidiaries in South Korea (Hobday, 1995, p. 53).

The success of the chaebol has been quite impressive. Nevertheless, as it has been described in section 1, all of these firms still depend on Japanese technology for hightech inputs and machinery. The technological gap between Korean and Japanese firm seems to widen. Overall, one could claim that even though some chaebol possess Oadvantages and have been able to invest abroad, the South Korean entrepreneurial class does not enjoy similar innovative and management capabilities than its counterparts from the advanced OECD economies.

From the account of the emergence of the chaebol described above, can one expect the Chinese firms to imitate the chaebol's impressive -though not quite complete- catching up of the most technologically advanced competitors from the US, Japan or the EU? What is certain is that the path taken by the chaebol or by the Japanese zaibatsu-keiretsu during the $20^{\text {th }}$ century is blocked for Chinese firms. China will not benefit from the exceptionally favourable environment enjoyed by Japanese and then South Korean newcomers because of three major changes in the world economy and one characteristic of the Chinese economy. 


\section{Four differences between China and the development of the East Asian advanced economies}

\section{A different international environment} the United States, towards China is completely different from the special relationship enjoyed by East Asian economies like Japan, South Korea or Taiwan. In the 1950s, 1960s and 1970s, these countries benefited from massive financial aid packages (Lanzarotti, 1992). As important, they also received freely substantial technology and managerial know-how transfers because of the context of the Cold War (Friedman, 1993, p. 275). The US provided the Japanese and South Korean manufacturers with an important outlet for their exports during the Korean and Vietnam wars (Samuels, 1994, p.133; Cook, 1996, p.170). The procurements of the American army accounted for more than $70 \%$ of the Japanese exports from 1950 to 1952 (Samuels, 1994, p.133). As it has been mentioned before, the USA had a sufficient leverage to impose the reintegration of Japan in the international capitalist community and to push for the accession of Japan or South Korea in multilateral institutions like the GATT or the OECD. Furthermore, South Korean exports were given a preferential access to the US market until the 1980s (Jones, 1997, p. 79).

The attitude of the United States and the other OECD economies towards China today is very different from what experienced Japan or South Korea decades earlier. The rate of growth of the OECD economies is considerably slower today than during the 1960s and 1970s. Despite considerable progress in liberalisation of trade during the Uruguay round of the GATT, the United States have been using more often unilateralist protectionist measures (Van Der Wee, 1990, p. 334; Rainelli, 1996, p.107; Pantz, 1998, p. 58; Ito, 1996, p. 375). President Bush considers China as a "strategic competitor" rather than "a strategic partner". China has faced very harsh conditions imposed by both the US and the EU during the negotiations for its accession to the WTO in 1999. China has been imposed a "transitional product-specific safeguard mechanism" (TPSSM) that enables until December 2013 WTO members to impose special tariffs on Chinese exports should they increase fast and create "a market disruption". China's accession protocol to the WTO was certainly the harshest imposed on any new member by the United States (Holbig, 2002, p.25). In 2004, China is still being refused to be granted the "market economy" status by the US and the EU. This offers WTO members a wider degree of freedom in launching antidumping cases against Chinese exports (paradoxically this status was given to Russia when most experts on transition economies believe that China is more advanced in its transition toward a capitalist market economy). Thus, China's access to international markets is subject to potential discretionary unilateral protection measures by any WTO member.

\section{More obstacles to the acquisition of technology by Chinese firms}

The acquisition of technology will be more difficult for Chinese than for their Japanese and Korean counterparts. China can be certain not to benefit from the free transfer of technology of the cold war mentioned above. On the contrary, the new rules imposed by the WTO make technological acquisition more problematic than during the youth of the chaebol. At the Uruguay round of negotiations (1986-1994), the OECD business 
community called for the creation of a multilateral institutional framework to enforce the intellectual property rights (Hoekman, 2001, p. 279). Copyright protection has been extended to a minimum of 50 years and its coverage extends to programs and data (Hoekman, 2001, p. 285). Industrial design and integrated circuits design are protected for a period of ten years (Hoekman, 2001, p. 286). Almost all inventions are protected by a patent of at least 20 years (Hoekman, 2001, p. 288). The development of the IPR rules has created a completely new environment for the emerging firms of developing countries compared to the situation of the 1960s, 1970s and 1980s when the Asian NICs upgraded their technology, often in a manner that would now considered non compatible with the WTO IPR rules.

The Chinese government has been using various mechanisms to attempt to funnel foreign technology. Thanks to its potentially huge domestic market, the bargaining position of the Chinese government could impose technological transfers by MNEs investing in China. Many MNEs were forced to joint venture agreements which sometimes required technology transfer (APCO, 2003, p. 43) while others had to develop R\&D facilities in China (Kim \& Lee, 2004, p. 16). Chinese authorities were very lenient on copyright abuses by Chinese firms. Regulations over IPR were very loose in China before its accession to the WTO. When such legislation existed, it was seldom enforced. For example, in 1992, the Shenzhen Reflective Materials Institute was found to have copied 650,000 Microsoft Corporation trademark holograms. After two years of judicial procedure, the Institute was fined only $\$ 252$. In contrast Chinese courts have imposed the death penalty for those who have traded in famous liquor and cigarettes and the trademark holder was awarded compensation of $\$ 115,000$ (Gregory, 1990, p.330). Furthermore, domestic firms do not always pay the fine and it is not always fully collected by the courts (Gregory, 1990, p.331). The leniency of Chinese courts on IPR violation has enabled Chinese firms to access cheaply to some foreign technology.

However, these mechanisms of technology transmission might prove more difficult to apply for three reasons. Firstly, in order to join the WTO, China had to adopt a legal framework to enforce IPR in China. Progress in that area have been slow the two first years after China's accession but they have been accelerating these last 18 months under the pressure of the US, Japan and the EU (APCO, 2003, p.43). IPR violations are likely to decrease or China might face unilateral and multilateral sanctions. Secondly, when MNEs operating in technology intensive sectors decide to set up in China, they increasingly opt for the creation of a wholly foreign-owned subsidiary rather than to enter in a joint-venture agreement with a Chinese partner (Luo, 2000, p. 26 \& APCO, 2003). Thirdly, China's bargaining position could weaken as other large economies are getting more attractive to MNEs both in terms of market size and skilled labour. The recent transformation of the Indian economy is generating a magnet for FDI. The ASEAN economies are trying to transform the ASEAN Free Trade Area as a truly integrated market for goods and service. If the objectives of the Concord II project decided in the ASEAN summit of Bali in November 2003 are met, then it could strengthen the ASEAN attractiveness to MNEs relatively to China's. Nesadurai has pointed out that some MNEs are already developing a "two-pronged investment strategy" between China and the ASEAN, deciding to opt for one country or the other according to the local environment provided to host FDI (Nesadurai, 2003, p.185). If such occurrences take place, the Chinese authorities will not be able to impose on MNEs too demanding conditions over technology transfers. 
Although the Chinese government's latitude will be limited by the factors mentioned above, there is still scope for potential technology transfer from MNEs through human capital. Even without government pressure or incentives, many MNEs prefer to invest R\&D facilities in China to improve "time to market" and to be able to react quicker to a volatile demand keen on new differentiated products (Kim \& Lee, 2004, p.16). Some MNEs have recently established R\&D centres for product development aimed at the Chinese market (Chen, 2004, p.13). MNEs are attracted by the cheap price and availability of high-quality Chinese engineers (Chen, 2004, p.13). This enabled world class firms like IBM, Microsoft, BAE, Motorola and Intel to engage in basic technology research in China in collaboration with Chinese universities and state-funded research institutes (Chen, 2004, p. 14; APCO, 2003, p. 45). Marshallian districts in R\&D (clusters of laboratories, pool of qualified personal, improved higher education institutes) could emerge and generate external economies of scale which could in the mid run benefit indirectly to Chinese firms. However one must keep in mind that most of the R\&D facilities built in China by MNEs target product development research. Product innovation and fundamental research are not pursued by MNEs subsidiaries in China. In that strategic field, China is still lagging far behind OECD economies and even behind India (APCO, 2003, p.45). There is still no evidence of major Chinese technological leaders in their sectors that could compare with the chaebol in terms of indigenous technological innovation capabilities. Chinese firms in technology-intensive sectors are small in scale and scattered (APCO, 2003, p.44). Furthermore, they face skilled-labour shortages because of the creaming-off made by MNEs. Overall the Chinese firms willing to develop world class indigenous innovative capabilities still face the four challenges outlined above. They display no ability in the mid-run to leapfrog the Western and Japanese MNEs which remain the incontestable technological leaders of the region.

Another way to develop technological capabilities is for the State to create the infrastructure for the private sector. South Korea, Taiwan and Singapore have been very active in this field for decades. The Chinese government lags far behind in terms of R\&D spending compared to other emerging industrialised economies. The Chinese government has launched its five-year "863 Programme" directed to eight strategic sectors: biotechnology, IT, automation, energy, advanced engineering, marine sciences and aerospace. The budget of this programme, if respected, is the double of the preceding one, reaching US\$84.3 billion (APCO, 2003, p. 44). This is still far from the OECD standards: the EU economies will spend together more than 1000 billions during the same period (CEPII, 2004, p.105; Devoluy, 2004, p.223). The latitude of the government on this matter is also limited because of the fast increasing public deficit and public debt (see below).

\section{A domestic market contested by MNEs}

Thirdly, the global economic environment has changed compared to the 1960s and 1970s. These two decades were characterized by high growth rates in the OECD countries. Most of the FDI flows were directed towards Europe and the US then considered as the main markets. East Asia was not a priority for Western MNEs, some of which were actually disinvesting out of the region (Yamamura, 1997, p. 37; Yoshihara, 1988). Since the 1990s, Western MNEs have focused much more on East Asia and the US government has adopted a tougher stance on more open rules for trade and investment 
in the region. It means that the infant industries of China face much tougher competition on their regional markets than their Japanese or Korean counterparts did.

In the case of Korea, the development of the chaebol can be divided in three stages. During the first one that occurred in the 1960s, the economy was quite open to FDI and the chaebol gained technological and management know-how through their subcontracting agreements with the subsidiaries of MNEs. During the 1970s until the mid 1980s, the South Korean government adopted a much more restrictive policy on FDI inflows. They forbade the presence of MNEs in some industries and services, some firms were even force to close their subsidiary. Thanks to this privileged access to their domestic market, the chaebol benefited from economies of scale and learning by doing effects which increased their competitiveness. This opened the way for the third stage, the transformation of the chaebol into MNEs that began to open subsidiaries in the OECD economies. In the case of the Japanese keiretsu, MNEs had only a very limited presence in Japan after WWII. Before 1974, the Japanese financial markets were completely isolated from foreign financial operators due to high controls on international capital flows (Ito, 1996, p.316). FDI inflows have been much lower than the average of the OECD economies (IMF).

Chinese firms face a completely different situation. As it has been mentioned before, the MNEs account for a very important part of the domestic gross capital formation. Their shares on the various Chinese markets and in the Chinese exports have been rising constantly these last two decades generating a growing fear among Chinese firms (Huang, 2003, p. 16 \& p. 334). Furthermore, since MNEs have been welcomed to invest in China, they have received a privileged treatment from the central and local authorities in terms of infrastructure and taxation compared to the Chinese private firms (Lemoine, 2004, p. 36). These three last years, the government is reversing slowly this policy. It claimed that it was thinking about phasing out the special incentive programs for FDI to put MNEs on an equal footing with Chinese firms.

\section{A domestic market fragmented by competing provincial champions}

Not only will Chinese firms have to compete with more advanced firms on their domestic market, but the degree of integration of the latter is far lower than those of Korea and Japan in the 1960s. Most of the Chinese domestic market is located in the coastal and central provinces. The Western mountainous and desert provinces (Tibet, Yunnan, Xinjiang, Quinghai and Inner Mongolia) account for only a minor share of China's population and GDP. The lack of infrastructure of the Western provinces might weaken political cohesion if the divide continues to widen with the richest coastal province. However, the coastal and central province could constitute a sufficient potential market if they would be well integrated. In terms of transport, the infrastructure for overseas transport is much more developed than the inland transport systems. Travel time for freight between Shangai and Seattle is shorter than between Shangai and Chongquing, located only 1600 kilometres away (The Economist, 2001, 10/3/01). During the 1990s, 1000 kilometres of highway were built each year but the Chinese transportation system is still very inefficient by international standards (Luo, 2000, p.113).

However, the main cause of the fragmentation of the Chinese domestic market is not natural geographic obstacles or the transport infrastructure but the protectionist 
policies adopted by the local authorities. Since 1978, provinces and counties have gained a tremendous economic autonomy. In order to increase revenue and to check the unemployment generated by the reforms, the provincial and municipal authorities began to pursue import-substitutions policies and to develop provincial champions in capital-intensive consumer industries such as automobile, television and household appliance. To nurture their infant provincial champions, they began to protect their provincial market from foreign competitors but also from the Chinese firms originating from other provinces, sometimes crossing the limits of legality to achieve their aim.

During the 1980s, provincial tolls were imposed at the provincial and even county level. Wedeman mentions the example of the 620-kilometer Liaoning section of the BeijingHarbin highway which was cut by 45 permanent and 120 temporary inspection posts to tax imports, one every $3.8 \mathrm{~km}$. Many provinces on the coast, in the interior or in the West erected thousands of tolls, some completely illegal (Wedeman, 2003, p.182). In 1989, the interregional domestic trade in the words of Wedeman "had begun to resemble trade in medieval Europe or in pre-1911 China" (Wedeman, 2003, p.1987). Apart from tolls, the government also imposed other forms of tariffs and non-tariff barriers.

Local governments pressured provincial courts to discriminate against firms originating from provinces in commercial disputes. Local officials falsified evidence or in some instance even connived with criminals to intimidate court officials (Wedeman, 2003, p.167). The same occurred with local banks. Preferential rates were given to local firms. Local banks went as far as refusing payments to non-local bank accounts or checks issued to outsiders (Wedeman, 2003, p. 165).

These provincial economic wars have peaked in the early 1990s and even caused some concerns in international institutions like the World Bank who questioned the ability of the central state to enforce the free movement of goods across China. Since then, many tolls were lifted in many of the coastal provinces but still exist in the inland provinces. The practice of provincial tariffs barriers is far from over. As late as 1998, the Shanghai authorities decided to impose special tax of 15,000 RMB on automobiles not produced in its municipality (Posth, 2002, p. 93). In 2003, taxi companies in Beijing and Shanghai still had to buy a part of their fleet from local automobile joint-ventures (e.g. VW for Shanghai and Hyundai for Beijing).

One could argue that some of these coastal provinces have a larger population than South Korea and therefore, some of these Chinese provincial champions could hope to benefit from economies of scale to the same extent that their Korean predecessors did. Notwithstanding the fact that the GDP of most of these provinces is still much lower than South Korea's in the late 1980s (Maddison \& OCDE, 2002), the main flaw of this argument however is that it does not take into account the changes in technology and in the production process that took place between the mid 1980s (when the chaebol emerged as global competitors) and the 2000s. Various studies of economies of scale in the OECD have shown that the minimal efficient size has risen considerably in most of the technology and capital intensive industries (Aujean, 1986, p. 42; Davies, 1998, p.113, Economie Européenne 2, 1994, p.5; Defraigne, 2004, p.251). A domestic market that could have been considered twenty years ago as sufficiently large to benefit from economies of scale and learning by doing effects, would be far too narrow for today's firms with the current technology. 

over their Chinese competitors prevent the emergence of large national champions that could benefit from the potential economies of scale secured by a large integrated domestic market and acquire O-advantage due to experience in large-scale production. The result has been the proliferation of small-size enterprises in capital intensive sectors such as automobile, refrigerators and other household appliance. For example, in 1998, there were 115 motor vehicle assembly firms in China, operating on average at less than 15,000 units per year (Huang, 2003, p.260). This is to compare with the ten biggest MNEs whose each produces more than 1,500,000 vehicles a year (Dicken, 2003, p.374).

\section{Acquiring 0-advantages through an ambitious industrial policy?}

The central government of China is well aware of the scale and integration problems that Chinese emerging firms are facing. It has been trying for almost a decade to integrate the domestic market and to develop Chinese national champions.

The central government has imposed the lifting of many internal trade barriers. The accession to the WTO might help it to reassert its authority on Chinese provinces as the WTO accession protocol does not recognize the provincial level of authority but only the national level. This enables the central government to claim that provincial barriers must be lifted in order to comply with multilateral trade rule and continue to access world markets (Kewalram, 2003, p.415). According to Wedeman, the price wars between provincial champions of 1998-2000 have let on that provincial authorities have decided to allow inter-provincial competition and not to raise trade barriers (Wedeman, 2003, p.234). This is a good indicator that after having reached a peak in disintegration in 1990, China is moving towards the integration of internal market again.

79 Since the 1980s, the Chinese government has expressed the will to develop national industrial champions (OCDE, 2002, p.39). When China joined the WTO, the central government has also established a list of national champions in key industries (Nolan, 2002, p.57) The SASAC (State assets supervision and administration Commission) was given full authority on 196 SOEs whose assets are worth 834 billions dollars and constitute $55 \%$ of all state assets. These SOEs are the major producers in oil, steel, aerospace, automobile and telecoms. The idea is to merge the 196 existing SOEs into 30 to 50 industrial national champions (Le Monde, 08/08/2003). These firms are given preferential treatment in access to credit, raw materials and government contracts. Nevertheless many analysts are sceptical of the success of this industrial policy.

Most among the few Chinese brands known globally like Haier and Kelon are private enterprises. Lenovo is officially a SOE but its managers negotiated exceptionally well with the State authorities to get the operating autonomy of a private firm (Huang, 2003, p.129). Lenovo has also been able to use efficiently the "one country-two systems" which characterizes the relations between Honk-Kong and the mainland. Most of its activities on the mainland are made by subsidiaries of its Hong-Kong branch which benefits from a larger degree of autonomy vis-à-vis the state thanks to the island capitalist institutional structure (Huang, 2005). Furthermore, none of these three firms were forced to merge with a partner imposed by the State authorities. These firms have beaten State-owned champions which benefited from massive government support,

Belgeo, 3 | 2005 
larger capital investments and a privileged access to credit (Huang, 2003, p.190). Four main factors are responsible for the inefficiency of SOEs.

81 Firstly, despite the fact that the Chinese economy is clearly engaged into its transition towards capitalism, many SOEs are far from being fully market-oriented as they have to take political and social objectives into account. They provide a number of social services in housing, education, health and leisure to their local community. They are clearly overstaffed as they also have to follow to employment objectives set by local and central states authorities. As for mergers, the champions targeted by the government are merged with overstaffed inefficient firms (Nolan, 2002, p. 57). This type of merger imposed by the government does not induce necessarily productivity gains. Often such mergers are not accompanied by a rationalisation of production capacities. They lead to giant enterprises disposing of uncoordinated similar small units of production (Nolan, 2002, p.57). This absence of synergy means that the Chinese champions do not benefit from economies of scale. A situation which bears some analogy with the merger policies adopted by the British government in the 1960s and 1970s which lead to some disasters like British Leyland (Prais, 1974, p.155; Owen, 1983, p. 80).

82 Secondly, during the last two decades, most SOEs have been riddled with the misappropriation of their assets by their managers. The "contract-responsibility" system launched in the 1980s has given the SOEs a greater control on their profits. Enterprises were authorised to keep the profits they made on quantities produced beyond the quotas established by the State plan (Lemoine, 2004, p.23). Because of this semi-planned system, SOEs' managers could order more raw materials than needed for their production purposes and sell them back to private enterprises on the black market. In the same manner, they could also benefit from credits at preferential rates and re-lend them to private firms desperate for more liquidity. According to Chinese economists, this phenomenon of misappropriation of SOEs assets called guandao (meaning in Chinese "trade off by officials") amounted to 350 billions RMB ( $\$ 40$ billions) in 1988, almost $25 \%$ of China's GDP (Lin, 1994, p. 206). The Chinese officials recognise that between 1990 and 1995, a tenth of the state budget disappeared through guandao (Lemoine, 2004, p. 25). In 2000, an official audit revealed that at least two thirds of the SOEs continued to falsify their accounts despite the repeated attempt to improve corporate governance (The Economist, 03/03/01, p.72). The capital gains are most often expatriated to overseas safe havens such as the Virgin Islands or to Hong-Kong. Then they are reinvested to the mainland as FDI benefiting from the protection of property rights given to foreign investors. Some ends up in real estates, the stock markets or other type of speculation. Other are invested in private firms in the same branch of activity that the SOEs whose capital has originally been misappropriated. This phenomenon clearly weakens the efficiency of any state subsidies or merger policies.

Thirdly, the deteriorating state finances restrict any ambitious industrial policy in terms of subsidies and R\&D. The share of the budget of the central state in the GDP has shrunken by almost two-third since the reforms were launched in 1978 (Chinese Statistical Yearbook, 2003). The public deficit has broken successive records each of the last two years and stands now above 3\% (Financial Times, 06/03/03). The official state debt amounts to $20 \%$ of the GDP but if one adds the non-performing loans of the stateowned banks (50\% of the GDP according to Western analysts) and the liabilities that will 
be generated the future welfare system organised by the state, the real debt of the Chinese state is bigger than its GDP (The Economist, Survey of China, 08/04/00; Lyons, 2003). With total state revenues amounting to less than $20 \%$ of the GDP in 2003 (half of the European average) (OCDE, 2002, p. 30), the debt of the Chinese state can cause some concerns over the feasibility of an ambitious industrial policy to build up national champions with innovative capabilities.

Lastly, the government must also prevent the multiplication of competing industrial policies between the various provinces. The share of the State spending controlled by the local authorities has been rising during two decades (Lemoine, 2004, p.34). This enable provinces to encourage their infant champions to compete with established provincial champions. The automobile sector reflects that problem. In autumn 2003, the Chinese government has tried to restrict entry by new firm in this sector. The objective was to prevent the duplication of production units in a sector already riddled by overcapacities but the central state could not prevent some provincial champions specialised in household appliance to attempt producing motor vehicles (FT, 18/09/03).

\section{Conclusion}

The Chinese entrepreneurs and the central government face a challenge never experienced by preceding industrialised latecomers. The new geopolitical environment, the new strategies of MNEs and the new multilateral institutions are putting Chinese firms into a completely different situation than the one encountered by the Japanese keiretsu or by the Korean chaebol. The technological transfers necessary to catch up with the global competitors and break away from the "flying geese" pattern seem much more difficult to achieve for Chinese firms today than it was for their OECD counterparts decades ago.

This difficult situation could prevent the emergence of a dynamic Chinese entrepreneurial class willing to achieve autonomy in managerial know-how and technological innovation. In that case, Chinese capital holders, like most of their ASEAN counterparts, would probably turn into comprador capitalists specialised in subcontracting activities for foreign-based MNEs or sheltered into state-protected sectors. The Chinese economy would follow the path of "ersatz capitalism" development described by Yoshihara and could not catch up with the most advanced flying geese.

To avoid this fate, the Chinese central government has been fighting on four fronts. Firstly, it is attempting to complete the integration of its domestic market in order to let its biggest domestic firms benefit fully from the economies of scale. This necessitates the suppression of internal barriers and of competing provincial industrial policies. Secondly, the Chinese government will probably have to delay as long as possible (that is as long as China's trading partners do not take drastic countermeasures) the application of many of its WTO commitments, especially in matters of IPR and in the opening of the domestic market in strategic sectors. Thirdly, it is attempting to discipline the Chinese banking system in order to channel more efficiently the Chinese savings to the efficient enterprises and to control the flow of cheap credits that end into counterproductive investments. Lastly, the Chinese government is trying to develop its infrastructure and human capital in R\&D by increasing the budget in these fields. The analysis above has shown that these objectives are far from being reached so far. 


\section{BIBLIOGRAPHY}

ADELPHI (1994), “China changes shape: Regionalism and Foreign Policy”, Adelphi Paper, 287.

APCO (2003), Report on EU FDI in China, Beijing.

AUJEAN M., CATINAT M., EMERSON M., GOYBET P. \& JACQUEMIN A. (1992), 1992: La Nouvelle Economie Européenne, De Boeck, Bruxelles.

BESELER H.-F. (2002), "The EU-China Negotiations: Breaking the Deadlock" in "China and the WTO: The Challenge for China's Large-scale industry" in HOLBIG, H. \& ASH R., China's accession to the world trade organization, Routledge Curzon, London.

CEPII (2004), L'Economie Mondiale 2005, La Découverte, Paris.

CHANDLER A. D. (1994), Scale and Scope, Harvard University Press.

CHEN T.-J. (2004), "Living under the Roof of WTO: Cross-Strait Economic Relations since WTO accession"Rising China and the East Asian Economy, Korea Institute for International Economic Policy, Seoul.

CHO H. (2004), "China's approach towards FTAs with East Asian Nations and its implication for Korea" in Rising China and the East Asian Economy, Korea Institute for International Economic Policy, Seoul.

COHEN J.B (1946), Japan's Economy in War \& Reconstruction, Washington.

COOK I. G., DOEL M. A. \& LI R. (1996), Fragmented Asia: Regional Integration and National Disintegration in Pacific Asia, Avebury, Aldershot.

DAVIES R.W. (1998), Soviet Economic Development from Lenin to Krutshchev, Cambridge University Press.

DAVIES S. \& LYONS B. (1996), Industrial Organization in the European Union: Structure, Strategy and the Competitive Mechanism, Clarendon Press, Oxford.

DEFRAIGNE J.-C. (2003), De l'intégration nationale a l'intégration continentale: Analyse de la dynamique d'intégration européenne et de ses liens avec les changements technologiques dans une perspective de long terme, Thèse de doctorat, Université Libre de Bruxelles.

DEVOLUY M. (2004), Les Politiques Economiques Européennes: Enjeux et Défis, Seuil, point économie, Paris.

DICKEN P. (2003), Global Shift: reshaping the global economic map in the $21^{\text {st }}$ century, Sage publications, London.

DICKSON I. (2003), "China's interest in the World Trade Organization's deregulation" in CASS D., WILLIAMS B. \& BARKER G. (2003), China and the World Trading System: Entering the New Millenium, Cambridge University Press.

DONER R. F. (1993), “Japanese Foreign Direct Investment and the Creation of a Pacific Asian Region", in FRANKEL J. \& KAHLER M., Regionalism and Rivalry: Japan and the United States in Pacific Asia, NBER, University of Chicago Press.

DRYSDALE P. \& ZHANG D. D. (2000), Japan and China: rivalry or cooperation in East Asia?, AustraliaJapan Research Centre, Canberra. 
ECONOMIE EUROPEENNE (1994), Fusion et Acquisition, Suppplément A, février 1994, Office des publications officielles des Communautés Européennes, Luxembourg.

FRIEDMAN, D. \& SAMUELS R. (1993), “The Japanese Aircraft Industry and Japan's Technology ideology" in FRANKEL J. \& KAHLER M., Regionalism and Rivalry: Japan and the United States in Pacific Asia, NBER, University of Chicago Press.

FUKASAKU K. (1992), “Economic regionalisation and intra-industry trade: Pacific-Asian perspectives”, OCDE/GD (92)5, Paris.

GEE S. (1992), “Taiwanese corporations in globalisation and regionalisation”, OECD/GD (92)62, Paris.

GREGORY P. R. (1990), Soviet Economic Structure and Performance, Fourth edition, Harper \& Collins, New York.

HATCH W. (2000), "Japanese production networks in Asia" in STUBBS R. \& UNDERHILL G., Political Economy and the Changing Global Order, Second edition, Oxford University Press.

HIGGOTT R. (2000), "Regionalism in the Asia Pacific: Two steps forward, one step back" in STUBBS R. \& UNDERHILL G., Political Economy and the Changing Global Order, Second edition, Oxford University Press.

HOBDAY M. (1995), Innovation in East Asia: the Challenge to Japan, Edward Elgar, Aldershot.

HOEKMAN B. \& KOSTECKI M. (2001), The Political Economy of the World Trading System, Oxford University Press.

HOLBIG H. \& ASH R. (2002), China's Accession to the World Trade Organization, Routledge Curzon, London.

HUANG Y. (2003), Selling China: Foreign Direct Investment during the Reform Era, Cambridge University Press.

HUANG Y. (2005), China's big hope is not Hong Kong, Financial Times 13/01/2005.

HUNTER J. (1989), “The Emergence of Modern Japan”, Longman, London.

ITO T. (1993), "US political pressure and economic liberalization in East Asia”, in FRANKEL J. \& KAHLER M., Regionalism and Rivalry: Japan and the United States in Pacific Asia, NBER, University of Chicago Press.

ITO T. (1996), The Japanese Economy, MIT Press, Cambridge, Mass.

JONES D. M. (1997), Political Development in Pacific Asia, Polity, Cambridge.

KATZENSTEIN P. \& ROUSE M. (1993), “Japan as a Regional Power in Asia”, in FRANKEL J. \& KAHLER M., Regionalism and Rivalry: Japan and the United States in Pacific Asia, NBER, University of Chicago Press.

KEWALRAM R. (2003), “WTO dispute settlement and sub-national entities in China”, in CASS D., WILLIAMS B. \& BARKER G., China and the World Trading System: Entering the New Millenium, Cambridge University Press.

KOHAMA H. (2004), “Japan's economic development and foreign trade”, in LEE C. \& YAMAZAWA I., The Economic Development of Japan and Korea.

KRUGMAN P. (1994), “The Myth of Asia's Miracle”, Foreign Affairs, 73(6), pp. 62-68.

LARDY N. R0. (2002), Integrating China in the Global Economy, Brookings Institution Press, Washington DC. 
LANZAROTTI Mario (1992), La Corée du Sud: Une sortie du sous-développement, IEDES, PUF, Paris.

LEE C. J. (2004), Korea's Initiative for a Northeast Asian Business Hub, Conference paper, KIEP.

LEMOINE F. (2004), L'Economie Chinoise, La Découverte, Paris.

LIN J. Y., CAO F. \& LI Z. (1994), The China Miracle: Development strategy and Economic Reform, The Chinese University Press, Hong Kong.

LINCOLN E. J. (1992), “Japan's rapidly emerging strategy toward Asia”, OECD/GD (92) 59, Paris.

LIU F.-K. (1996), "Industrial development and the impetus to regional economic integration in Pacific-Asia” in COOK I. G., DOEL M. A. \& LI R., Fragmented Asia: Regional Integration and National Disintegration in Pacific Asia, Avebury, Aldershot.

LUO Y. (2000), Multinational Corporations in China: benefiting from structural transformation, Copenhagen Business School Press.

LYONS G. (2003), China: The case for regulatory change and economic reform, Standard Chartered, London.

MADDISON A. (1995), L'Economie Mondiale 1820-1992: Analyse et Statistiques, OCDE, Paris, 1995.

NAKAMURA T. (1995), The Postwar Japanese Economy, Tokyo.

NAM Y.-S. (2004), "Facing the Challenge of China's Industrial Rise: The Korean Case", in Rising China and the East Asian Economy, Korea Institute for International Economic Policy, Seoul.

NESADURAI H. E. S. (2003), Globalisation, Domestic Politics and Regionalism: The ASEAN Free Trade Area, Routledge, London.

NOLAN P. (2002), "China and the WTO: The Challenge for China's Large-scale industry”, in HOLBIG H. \& ASH R., China's accession to the world trade organization, Routledge Curzon, London.

OMAN C. (1994), Globalisation and regionalisation, OCDE, Paris.

OWEN N. (1983), Economies of Scale, Competitiveness and Trade Patterns within the European Community, Calrendon Press, Oxford.

PANTZ D. (1998), Institutions et politiques commerciales internationales: du GATT à l'OMC, Armand Colin, Paris.

PETRI P. (1993), “The East Asian Trading Bloc: an analytical history”, in FRANKEL J. \& KAHLER M., Regionalism and Rivalry: Japan and the United States in Pacific Asia, NBER, University of Chicago Press.

POSTH M. (2002), “The Automobile Sector”, in “China and the WTO: The Challenge for China's Large-scale industry", in HOLBIG H. \& ASH R., China's accession to the world trade organization, Routledge Curzon, London.

PRAIS S.J. (1974), The Evolution of Giant Firms in Britain: a study of the growth of concentration in manufacturing industry in Britain 1909-1970, Cambridge University Press.

RAINELLI M. (1996), L'organisation Mondiale du Commerce, La Découverte, Paris.

SAMUELS R . J. (1994), Rich Nation Strong Army: National Security and the technological transformation of Japan, Ithaca, New York.

STUBBS R. \& UNDERHILL G. (2000), Political Economy and the Changing Global Order, Second edition, Oxford University Press. 
SUM N. (1996), "Greater China and global regional-local dynamics in the post-Cold War era", in COOK I. G., DOEL M. A. \& LI R., Fragmented Asia: Regional Integration and National Disintegration in Pacific Asia, Avebury, Aldershot.

TSENG W. \& RODLAUER M. (2003), China, Competing in the Global Economy, IMF.

VANDERWEE H. (1990), Histoire Economique Mondiale: 1945-1990, Academia Duculot.

WEDEMAN A. H. (2003), From Mao to Market: Rent-seeking, Local Protectionism and Marketization in China, Cambridge University Press.

XIAO G. (2004), "Asia Team of Flying Geese: the Rise of China and Implications for Hong Kong SAR", Rising China and the East Asian Economy, Korea Institute for International Economic Policy, Seoul.

YAMAMURA K. \& HATCH W. (1997), Asia in Japan's embrace: building a regional production alliance, Cambridge University Press.

YOSHIHARA Kunio (1988), The rise of Ersatz capitalism in Southeast Asia, Oxford University Press.

\section{INSTITUTIONS STATISTICS, REPORTS \& PRESS}

China Statistical Yearbooks, 1985-2003.

IMF, International Financial Statistics, 1960-2003, International Monetary Fund, Washington.

MOFTEC, Statistics on FDI in China, MOFTEC, Beijing 2002, 2001, 2000.

OCDE, La Chine dans l'économie mondiale: les enjeux de politique économique intérieure, rapport de synthèse, Paris, 2002.

UNCTAD, World Investment Reports, United Nations, Geneva, 2001, 2002, 2003, 2004.

FINANCIAL TIMES, London.

FORTUNE, Global 500, USA.

LE MONDE, Paris.

LE MONDE DIPLOMATIQUE, Paris.

THE ECONOMIST, London.

\section{ABSTRACTS}

This article aims at analysing the insertion of the Chinese firms into the East Asian development process known as the "flying geese" pattern. Its main objective is to assess the capacity of the Chinese industrial champions to transform themselves into global competitive multinational enterprises and, therefore, the capacity of the Chinese economy to catch up with the most advanced East Asian economies like Japan or South Korea. It shows that Japanese and Korean firms are still the uncontested technological leaders of Asia and that the largest Chinese firms are far less capital intensive and profitable than their Japanese and South Korean competitors. Finally, this article looks into the global changes that have made extremely difficult for the Chinese industrial champions to follow the successful development path of their Japanese and South Korean competitors.

Cet article vise à analyser l'insertion des firmes chinoises dans le processus de développement est-asiatique, connu sous le nom de "schéma de développement en vol d'oies sauvages". Son objectif principal est d'évaluer la capacité des leaders de l'industrie chinoise à devenir des 
entreprises multinationales compétitives et, partant, la capacité de l'économie chinoise à rattraper les économies est-asiatiques les plus avancées comme celles du Japon et de la Corée du Sud. L'article démontre que les firmes japonaises et sud-coréennes sont toujours les maîtres incontestés de l'Asie en matière de technologie, et que les plus grandes sociétés chinoises sont beaucoup moins "capital intensive" et génératrices de profits que leurs concurrentes japonaises et sud-coréennes. Enfin, nous examinerons les changements globaux qui se sont traduits, pour les leaders de l'industrie chinoise, par des difficultés énormes pour arriver à suivre les voies d'un développement qui a si bien réussi au Japon et à la Corée du Sud.

\section{INDEX}

Mots-clés: économie internationale, économie est-asiatique, économie chinoise, IDE, multinationales, avantages spécifiques à la firme, capacités d'innovation, développement Keywords: international economy, East Asian economy, Chinese economy, FDI, multinational enterprises, ownership-specific advantages, innovation capabilities, development

\section{AUTHOR}

\section{JEAN-CHRISTOPHE DEFRAIGNE}

CCEEC, University of International Business and Economics, Beijing, jdefraigne@yahoo.com 